\title{
The effect of past health events on intentions to purchase insurance: evidence from 11 countries
}

\begin{abstract}
We investigate whether past negative health experiences are positively associated with intentions to purchase insurance to mitigate the risks of income losses due to illnesses and disabilities. Using an original survey based upon representative samples of working individuals in 11 countries, we show that agents who have personally experienced a negative health event in the past are $25 \%$ more likely to state the intention to purchase income protection insurance than those who have not had such an experience. Moreover, personally knowing someone who suffered from ill health increases intentions by $40 \%$. Insurance ownership increases by $23 \%$ due to personal experience and by $31 \%$ because of vicarious experience.
\end{abstract}

Keywords: Learning, experience, survey, insurance purchasing intentions, vulnerability

JEL: D03, D14, D12, I13, D83

\section{Introduction}

Increasing numbers of working people worldwide are vulnerable to changing labour markets. In their study of household financial fragility, Lusardi et al. (2011) sought to determine whether Americans could obtain US\$2000 within 30 days. It was found that about $25 \%$ of Americans surveyed reported that they could not do so while another $20 \%$ would have done so by "selling or pawning possessions or taking 
payday loans" (Lusardi et al., 2011, p.2). Their results suggest that the well-being of a significant segment of the working population is directly related to how they cope with or insure against events that could undercut their capacity to earn a living over the short-term and the long-term. This is also exacerbated by the fact that, under existing legislation, only $28 \%$ of workers worldwide are eligible for benefits should they become unemployed. Effective coverage is even lower, with only $12 \%$ of unemployed individuals actually receiving unemployment benefits worldwide (ILO, 2017).

Self-protective measures to mitigate the risks of future negative events, specifically income losses due to prolonged illness or disability, do exist. Income protection insurance is designed to do just that: it pays out a benefit equivalent to a substantial proportion of the policyholder's earned income (typically up to 70\%) in the event of a serious illness or disability that prevents them from working for a significant period of time. Nonetheless, income protection insurance uptake is still low. At the global level, only $4.4 \%$ of the total labour force is covered by voluntary social insurance which covers incapacity to work due to work-related accident or disease, resulting in suspension of earnings (ILO, 2017).

This paper contributes to the literature aimed at understanding how individuals form their intentions to purchase insurance. Previous research in economics and psychology has found an association between prior experience and the intention to purchase various types of insurance. However, although the importance of income protection insurance as a supplement to public assistance has been acknowledged, there has been virtually no academic literature, be it in economics or in behavioural science, on this type of insurance. This paper draws on insights from both these disciplines in order to shed light on the link between previous negative health events and the intention to purchase income protection insurance. We specifically test 
for the effect of personal health vicissitudes as well as those of one's acquaintances in determining intentions to purchase income protection insurance. The latter are crucial to our analysis in order to control for the explanation that personal past experience is associated with rational expectations about one's future health status.

We look for evidence of this linkage in an original and large survey based upon representative samples of working individuals in 11 countries. The survey questions individuals on a number of areas - including their knowledge and awareness of insurance-related topics, personal and vicarious past experience of income losses, personal health and well-being, financial risk tolerance, and financial literacy - in order to understand better the drivers of demand for income protection insurance. This data provides us with a thorough understanding of individual experiences which occur prior to intending to purchase income protection insurance. This represents a unique opportunity to investigate the link between intentions to purchase insurance and prior health experience, be it first- or second-hand. Additionally, the dataset contains a rich set of socio-demographic and employment-related data which allows us to control for possible confounding factors.

Our paper shows that both personal and vicarious experience substantially increase intentions to purchase income protection insurance policies. More specifically, we are able to claim that agents who have personally suffered from a negative health event in the past are $25 \%$ more likely to state they wish to purchase income protection in the future than those who have not had such an experience. Moreover, knowing someone who suffered from ill health increases future purchasing intentions by $40 \%$. We show that severe or more recent health events do not strengthen the effect of experience on intentions to purchase insurance. Our results remain robust even when controlling for risk aversion, insurance knowledge, and financial literacy. We also investigate the existence of possible discrepancy between intentions and ac- 
tual behaviour and provide evidence of a positive correlation linking past experience, be it first- or second-hand, and income protection insurance ownership. This suggests that experience affects intentions but also behaviour, although to a lesser extent.

The paper develops as follows. Section 2 reviews previous literature on experience and risk. Section 3 describes the data and our estimation strategy. In section 4 we present the respondents' characteristics whereas section 5 presents our results, followed by robustness checks in section 6 . Section 7 synthesises the results and their implications, outlining avenues for future research.

\section{Related literature}

Unanticipated interruptions in earned income are likely to disrupt households' financial resilience. The occurrence and resonance of these events is related to workers' increased vulnerability to illnesses and disability during their working lives, and to changing labour markets.

\subsection{Vulnerability and risks}

Recent research in medical epidemiology (Roth et al., 2017) has made available time series data on the yearly incidence rates of a wide variety of diseases in multiple

countries. Incidence measures the number of new (or newly diagnosed) cases of a given medical condition within a year out of 100,000 individuals. Incidence rates are relatively low if evaluated on a yearly basis. Nonetheless, the probability of falling sick increases significantly if a longer time span is evaluated. Individuals are increasingly at risk of suffering from ill health during their working lives. These instances are a major global policy concern. In 2011 the United Nations set out an ambitious plan to dramatically reduce the effect of cardiovascular and other diseases in all regions of the world (WHO, 2011). One the sub-targets of the UN's Sustainable 
Development Goal number 3 is to reduce by a third premature mortality rates of working individuals due to noncommunicable diseases such as heart diseases, stroke, and cancer.

At the same time, the fragmentation of the labour market has increased substantially over the last few decades. The prevalence of different types of 'non-traditional' employment, the rise and fall of entire industries, and the growth in the sharing economy have all brought greater uncertainty to the global labour market. Additionally, persistent national labour markets differences, which relate to very different institutions and policy practices underpinning individual welfare (Christopherson, 2002) exacerbate inequality. This uncertainty, together with the risk of contracting a serious disease and being unable to work, puts individuals at risk of losing income for significant or even prolonged periods of time. This is also exacerbated by the fact that, under current legislation, more than $62 \%$ of workers worldwide have no access to benefits should they become unemployed (ILO, 2017).

These risks are likely to increase the vulnerability of certain segments of society to immediate shortfalls in earned income. Self-protective measures such as income protection insurance policies could help vulnerable consumers to cope with these negative instances.

Income protection insurance must be purchased prior to actually needing it. As a consequence, the decision to purchase this type of insurance is an inter-temporal decision under risk and uncertainty. According to the neoclassical economics paradigm, individuals deciding whether to purchase insurance face a known probability distribution of possible future income losses and their cost (Pauly, 1990; Tennyson \& Yang, 2014). Therefore, demand should be higher among those with higher risks of income loss. Empirical studies on long-term care insurance confirm this prediction and find that people who determine themselves to be at risk of needing long-term 
care are more likely to purchase long-term care insurance (Oster et al., 2010; Zick et al., 2005; Zhou-Richter et al., 2010).

\subsection{Experience: a behavioural perspective}

Contrary to what these findings might suggest, income protection insurance uptake is still low. At the global level, only $4.4 \%$ of the total labour force is covered by voluntary social insurance which protects them against income shortfalls due to work-related disabilities or accidents (ILO, 2017). Low purchasing rates have been explained by non-rationality and more specifically by misperceptions of probabilities and inabilities to process information. Both these issues might have some bearing on income protection insurance uptake. Cutler \& Zeckhauser (2004) and Schwarcz (2010) state that if individuals tend to be overly optimistic about their future or consider the magnitude and/or the probability of the potential loss as negligible, insurance policies look unattractive (Kunreuther et al., 2013; Kunreuther \& MichelKerjan, 2015). The low rate of insurance uptake has in the past also been explained by high costs of gathering relevant information concerning these products (Kunreuther \& Pauly, 2004). Non-purchasers declare themselves to be overwhelmed by information (Curry et al., 2009).

Previous studies claim that past negative experiences could potentially overcome these hindrances (Weinstein, 1989; Tennyson \& Yang, 2014). Experience carries an informational value and thus can be considered "a great teacher" (Marx et al., 2007). Once a negative event materialises, its perceived threat becomes relatively high and individuals are likely to think that it might reoccur. Past negative instances might in fact improve people's ability to assess risks (Nisbett \& Ross, 1980), providing information about the diffusion of the hazard itself. Severe personal experience provides information about the consequences of the lack of preventive measures (Weinstein, 
1989) as well as about one's own personal vulnerability, (Kunreuther, 1996) raising awareness of the need for planning for the future. These studies suggest that experience can teach individuals how to plan and thus revise their intentions.

Additionally, people anchor their future beliefs on current feelings and past experience (Loewenstein et al., 2003). Past experience affects individuals' mental imagery which in turn affects cognitive evaluations and anticipatory emotions, that is, future visceral and affective reactions to risk and uncertainty (Loewenstein et al., 2001; Slovic et al., 2002; Marx et al., 2007). Individuals tend to relate current situations to their memories of the past. These autobiographical memories are called flashbulb memories (Brown \& Kulik, 1977): considered putatively indelible, they are likely to be recalled even in the distant future (Rubin \& Kozin, 1984). Given their vivid, "salient, and concrete" nature (Nisbett et al., 2004, p. 111), flashbulb memories are likely to prompt emotional reactions and shape individual imagery of the future. They have a greater influence on judgement than does abstract information (Loewenstein et al., 2001). This suggests that vivid instances carry higher evidential value for individuals than do 'pallid' statistics (Hamill et al., 1980).

These findings have been adopted in the economics literature to explain common patterns concerning the intention to adopt precautionary measures in a wide variety of areas. Kunreuther (1996) reported the results of in-person interviews with homeowners in flood-, hurricane-, and earthquake-prone areas, and found that having knowledge or having experienced substantial damages to one's property increases interest in purchasing an insurance policy against these risks. Gallagher (2014) looked at flood insurance and has shown that in the aftermath of these natural disasters, people are driven by more emotional reactions. Yechiam et al. (2006) documented the effect of experience on the intention to purchase safety devices which could prevent theft and thus the risk of financial losses. Maguire (1980) interviewed households 
who had experienced a burglary and found that among those who did not have an insurance policy against theft in the first place, the intention to purchase insurance increased by $43 \%$.

When it comes to health, Weinstein (1982) studied the role of specific illnesses and found that people who suffered from ill health in the past worry more about their health, revising upward their beliefs concerning the prevalence of that illness and its seriousness. Burling et al. (1984) reviewed existing literature on myocardial infarction and smoking behaviour. Roughly a third to a half of smokers who suffered a myocardial infarction self-reported having reduced or quit smoking in the aftermath of the event.

Recent work in economics documents that life experience can affect intentions and future behaviour also in seemingly unrelated domains. Malmendier \& Nagel (2011) showed that financial risk tolerance, stock market participation, and investment are positively correlated with macroeconomic shocks that individuals experienced over the course of their lives. Kim \& Lee (2014) show that exposure to warfare between the age of 4 and 8 exerts a strong and significant effect on individual risk aversion up to 50 years after the experience occurred. Similarly, Bernile et al. (2017) unveil that CEOs who were exposed to major fatalities due to natural disasters during their early childhood behave more conservatively and adopt less risky corporate policies. Bucciol \& Zarri (2015) document that having been the victim of a serious physical attack or having lost a child are associated with fewer and less frequent investments in risky assets.

Although most literature focuses on the relationship between personal experience and changes in attitudes, the decision to consider self-protective measures is not limited to one's own personal vicissitudes. In fact, according to Marx et al. (2007), people tend to relate their current situation either to their own experience or to 
that of others. Likewise, individuals build their behavioural repertoire by relying on their own past observations as well as on the experience of others (Aragones et al., 2005). For example, Robertson et al. (1972) showed that knowing that a close friend or a relative was seriously injured in a car accident increases the probability that seatbelts are used. Tennyson \& Yang (2014) showed that individuals who have been involved in long-term caregiving in the past are significantly more likely to intend to buy long-term care insurance policies for themselves. These studies thus suggest that peers' experience matters and potentially teaches people to overweight adverse outcomes.

To summarise, the literature above has generally identified a positive relationship between personal and vicarious experience and the intention to adopt precautionary measures such as insurance in multiple domains. However, to the best of our knowledge, no study has assessed whether a positive relationship between experience and intentions holds in the domain of income protection insurance. This represents the main objective and core contribution of this paper.

However, this study takes a further step and tries to cast some light also on the relationship between past experience and actual ownership. In fact, despite the positive relationship between past experience and the intention to adopt precautionary measures in the future, experimental studies on 'decisions from experience' clearly show that there are exceptions to this rule: past experiences might simply teach people to underweight rare events and thus ultimately prevent the adoption of self-protective measures.

In laboratory settings, Barron \& Erev (2003); Hertwig et al. (2004); Hertwig \& Erev (2009); Yechiam et al. (2005) showed that individuals underweight rare events and behave as though these could not happen to them. For example, Barron \& Erev (2003) studied repeated decisions from experience with immediate feedback 
and showed that most participants tend to choose the option with the highest expected loss over the better and safer one. Participants can only recall a small set of past experiences linked to each alternative (Yechiam \& Ert, 2007). And, since lowprobability events are by definition not likely to occur repeatedly, due to experience agents tend to give a lower weight to the probability of experiencing such episodes again. Peer effects can magnify these tendencies. Yechiam et al. (2008) showed that knowing about the outcome of the actions repeatedly taken by a peer fosters the adoption of risky behaviours, especially in case of rare losses.

This is also shown in Erev et al. (2017) wherein participants were asked to choose between a risky prospect that leads to a large loss (20 Shekels about $\$ 5)$ in $5 \%$ of the cases, and 0 in the other cases and a sure loss of 1 Shekel. Participants first chose one of the options based only on this description, and then played the game after experiencing the outcomes of previous trials. Without experience, individuals chose the risky option in $48 \%$ of the cases, whereas as a result of experience this proportion rose to $65 \%$. In these cases, past experience seems to reduce the likelihood that people will behave cautiously in the future.

Other studies have found similar effects of experience on risky behaviours outside of laboratory settings. Yechiam et al. (2006) showed that more experience reduces the effective use of safety devices. Whereas most subjects chose to buy an anti-theft detachable radio panel for their cars, its use declined after purchase. By analysing the effect of terrorist attacks in Israel, Yechiam et al. (2005) showed that, despite their initial sensitivity, local citizens learnt to discount the importance of these events over time and continued to attend coffee shops and hotels. Kunreuther (1996) showed that even insurance holders fail to renew their policy after not experiencing any flood-related loss for a year or more. Michel-Kerjan (2010) found that after major hurricanes, the demand for flood insurance increases significantly. Overall, however, 
specific sanctions had to be implemented to oblige home owners to purchase insurance if they resided in flood-prone areas.

In a nutshell, the effect and magnitude of experience might differ depending on whether we evaluate intentions or actual behaviour, suggesting a possible lack of correspondence between attitudes and actions. We will also account for this explanation and use our original dataset to investigate the possible existence of a 'planning-behaviour gap' in the context of income protection insurance.

\section{Data description and research methods}

\subsection{Data source}

The data used in this study was collected through an online survey that was designed and implemented in early 2016. ${ }^{1}$ The survey was based upon representative samples of working individuals aged 25-60 in 11 countries, including Germany, Italy, Spain, Switzerland, and the UK (Europe); Brazil, Mexico, and the USA (the Americas); and Australia, Hong Kong, and Malaysia (Asia-Pacific). The survey was explicitly meant to investigate income protection insurance uptake, along with perceptions of the risk of income loss and implications of such losses for well-being. A total of 11584 individuals completed the survey.

Several aspects of the survey make it useful for this specific study. First, all respondents were part of the working population. As income protection insurance is meant to protect individuals in case their income stream is interrupted or curtailed due to health contingencies which prevent them from working, we believe this

\footnotetext{
${ }^{1} \mathrm{~A}$ description of the survey design is provided in section $\mathrm{A}$ of the supplementary material. Additionally, the exact formulation of all questions used in this paper is provided in section B of the supplementary material. The data used in this paper and the code to reproduce tables and figures presented here can be found at DOI: 10.5287/bodleian:BDR6e1p6N
} 
represents the most suitable group of individuals to carry out this study. Second, respondents were not only asked about their current insurance status but also their intention to purchase income protection insurance if they did not currently hold it. Data on purchasing intentions provides important insights on consumers' financial planning and is key to achieving the objective of this paper. Meanwhile data on ownership can provide information on individuals' actual behaviour.

The third advantage of our survey is its scope. The survey in fact covers multiple countries and a large number of respondents. Previous research has tended to rely on a limited number of individuals, often in a single country (Tennyson \& Yang, 2014) and belonging to a single income group casting doubts about the generalisability of the findings. Additionally, according to Weinstein (1989), one of the main limitations of previous investigations on the role of past experience on financial choices relates to the lack of a control group. Weinstein (1989) claims that studying only those who were exposed to previous negative experiences might intrinsically provide a bias in the estimated role that adversities play in the decision-making process. We believe that the richness of our dataset allows us to avoid these methodological flaws. Our study relies on responses from numerous individuals residing in 11 different institutional and socio-economic environments. Among those surveyed, some have experienced negative events while others have not. Similarly, the richness of the dataset allows us to include in our empirical analysis the respondents' current age and self-assessed health status as proxies of insurance prices. This is a common practice in the literature to correct for the lack of price data for income protection insurance. 


\subsection{Empirical models}

As mentioned above, previous literature shows the existence of a positive relationship between experience and intentions to adopt self-protective measures. However, to the best of our knowledge, no study has assessed whether this same relationship holds for income protection insurance. We therefore wish to fill this gap and primarily answer the following research question: is first- or second-hand experience of illness- or disability-related income losses positively associated with future intentions to purchase income protection insurance?

We develop and estimate empirical models to specifically test the effect of previous experience after controlling for other individual characteristics which could potentially affect one's intention to purchase income protection insurance.

The core of our analysis relies on the estimation of a logit model with country and occupation fixed effects. The basic specification is presented in Equation 1.

$$
\operatorname{Pr}\left(\operatorname{Ins}_{i, c, j}=1\right)=F\left(\alpha+\beta \operatorname{PersExp} \operatorname{Ex}_{i, c, j}+\theta \operatorname{VicExp} p_{i, c, j}+\gamma \mathbf{X}_{i, c, j}+u_{c}+u_{j}\right)
$$

where $I n s_{i, c, j}$, our dependent variable, indicates a respondent's intention to purchase

income protection insurance, where $i$ indicates the respondent, $c$ her country of residence, $j$ her occupation. This variable is equal to one if the individual declares she wants to purchase this policy, and zero otherwise. The term $u_{c}$ stands for the country fixed effects which are included in all our regressions to remove the impact on insurance purchasing intentions of fixed country characteristics which are potentially correlated with our main regressor. $u_{j}$ refers to a set of occupation dummies. Since we specify a logit model to represent choice behaviour, $F(\cdot)$ refers to the cumulative distribution function of the logistic distribution. 
The variable $\operatorname{Persexp} p_{i, c, j}$ is an indicator variable which takes value one if the individual has previously personally experienced a loss of income for a range of physical or mental health-related reasons. We collected this information via question 11 in our survey which asked respondents whether, in their working life, they had ever personally experienced a loss of income due to eight possible physical conditions or two mental health issues.

Additionally, we also want to test whether knowing someone who in the past experienced income loss due to a serious illness or disability affects individuals' intentions to purchase insurance. Previous literature has highlighted the importance of social relations (Robertson et al., 1972; Brown \& Kulik, 1977). Moreover, although personal experience affects one's rational expectations of future health, the experience of others does not necessarily do so. For this reason we include in our model the dummy variable $V i c E x p_{i, c, j}$ which takes value one if the agent knows someone who has experienced loss of income for health reasons. We use question 24 to gather this information. These two variables represent the key regressors of our analysis.

$\mathbf{X}_{i, c, j}$ identifies a vector of controls. We seek to ascertain that experience is not just a proxy for perceived exposure to risk. Garofalo (1977) finds that victims of crimes or robberies think that their chances of being robbed or attacked in the future have gone up. Similarly Tyler (1980) finds that crime victims perceive themselves as highly likely to be targets again. Therefore, in line with Smith (1968), to disentangle perceived risk from experience per se we include a measure for self-assessed risk of losing income due to ill health. Specifically, in question 19c we asked participants to assess their perceived personal risk of experiencing a loss of income due to serious illness or disability, given their lifestyle, health, and work environment. We also include a measure of self-assessed health levels. Weinstein $(1982,1987)$ finds that individuals who have experienced an illness in the past reduce their tendency to 
claim that their risk of falling sick is below average. Bhattacharya et al. (2009) mention that the healthiest individuals tend to be optimistic about their longevity and that in general people make systematic mistakes in assessing their mortality risks. Therefore, we include in our regressions an indicator measure which is equal to one if the respondent believed themselves to be healthier than average at the time they participated in the survey. We retrieve this information via question 22 .

Additionally, we asked individuals to provide an assessment of their future wealth (question 40) and health (question 23). Using the answers to these questions, we create two indicator variables which take value one if the agent has claimed that her future health and income are likely to be higher than her current ones. These indicators capture the essence of optimism as intended by Puri \& Robinson (2007) who looked at the effects of longevity prospects and perceived market prospects on investment decisions. Including this information in our model is important as it could be argued that optimistic individuals have inflated expectations about their future which might reduce the effect of experience and thus future intentions to purchase insurance.

$\mathbf{X}_{i, c, j}$ also includes a number of variables including individual income level and a dummy for being an employee as well as other socio-demographic characteristics such as gender, number of people relying on the respondent's income, and the presence of children below the age of 18 in the family. We also control for age and years of schooling. These variables are included as they might independently affect individual perceptions of the need for an insurance policy or simply act as barriers to insurance purchasing decisions. 


\subsection{Measurement and identification}

Our objective is to establish a relation between individual intentions to purchase insurance and previous experience. Focusing on intentions allows us to bypass a clear identification issue.

Generally, one could measure income protection insurance uptake simply by asking respondents whether, beyond obligatory government benefits, they have insurance which protects their income against serious illnesses and/or disability. However, it could be that individuals purchase income protection insurance as they grow older, so in a cross-sectional dataset simply registering its ownership might underestimate insurance demand (Tennyson \& Yang, 2014). Additionally, in order to properly assess the link between insurance uptake and experience, it is important to know whether individuals purchased the policy before having personally experienced a negative health event or getting to know about someone who has. This information is not present in our dataset.

For this reason, in line with previous literature (Tennyson \& Yang, 2014), we rely on individual self-reported future intentions to purchase income protection insurance. We use this information as our dependent variable. All those individuals who did not hold income protection at the time of the survey were asked in question 17 whether they would consider buying such policy in the future. This question implicitly takes temporal dynamics into account and reduces the opportunity for biased estimates as it allows us to test whether (future) insurance demand depends on (past) experience. Answers to this question represent our preferred binary dependent variable as respondents who already have income protection insurance are omitted. Our analysis thus focuses on all those agents who do not yet have such policy but have or not a clear intention to purchase it. Although this significantly reduces our sample size, our identification is undoubtedly more solid. 
The second identification issue potentially affecting our study concerns the fact that experience might not be completely random. Individuals who have physically or mentally demanding jobs might be more exposed to risks of injuries or general negative health events. As a consequence they might be a priori more inclined to purchase insurance to counteract these risks. We address this issue by including a set of occupation dummies in all our model specifications.

In our opinion, therefore, the identification method presented above represents the one with the highest potential given the data available to us. Focusing on those respondents who did not have income protection insurance when surveyed but expressed a positive or negative intention to purchase such a policy, and controlling for a set of personal and work-related characteristics, allows us to provide a relatively unbiased answer to our research question.

In spite of the rich set of controls we cannot entirely rule out the existence of omitted factors which simultaneously affect exposure to personal experience and insurance purchasing intentions. For instance, personality traits, and their lower level facets, are omitted from our analysis due to data availability and they could in principle affect individual exposure to negative health events and well as intentions to adopt self-protective measures. We appreciate this potential bias in our estimation strategy. Amongst the BIG-5, we believe that conscientiousness and neuroticism would be the most relevant to our analysis. The first favours long-term planning, carefulness and industriousness; the latter instead reflects anxiety and reactivity to threats. As these traits have been found to affect work performance (Barrick \& Mount, 1991; Salgado, 1998), exposure to risks and uncertainties (Rustichini et al., 2016; Hirsh \& Inzlicht, 2008), it is plausible to expect that they would have some bearing in our analysis. However, we believe the omission of these traits from our models is likely to bias our estimates of experience downward. We would in fact ex- 
pect neuroticism to reduce exposure to experience and increase intentions to adopt self-protective measures, as it generally associated with higher aversion to risk and uncertainty. In the same vein, as conscientiousness favours long-term goals and is negatively associated with reckless behaviour (Rustichini et al., 2016), it might increase intentions to purchase insurance and reduce exposure to experience. Although the direction and magnitude of these biases cannot be confirmed and remain subject to future work, we believe that these omissions are likely to lead an underestimation of the true impact of experience on intentions, and therefore bias our results towards finding a null result.

\section{Sample characteristics}

In the full survey sample (i.e. 11584 individuals), 35\% of respondents own income protection insurance. Among those who do not own income protection insurance (i.e. 6481 agents), roughly $52 \%$ declare a positive intention to purchase it in future.

Table 1 provides some details on the characteristics of these 6481 respondents. These are reported for the full sample (i.e. 6481 agents) and by intention to purchase, distinguishing between those who lack intention and those who stated a positive intention.

In the first rows of table 1 we can observe respondents' previous health experience. The table shows that $62 \%$ of our respondents have had some form of negative health experience. Nearly $39 \%$ of the sample has personally experienced a negative health event in the past. Vicarious experiences are however more prevalent. $47 \%$ of our respondents know someone who lived through a negative health experience. Respondents who self-report a positive intention to purchase insurance in the future are more likely to have had negative past experiences, be they first- or second-hand, than those who express no intention at all. 
Figure 1 reports intentions to purchase in all countries depending on whether individuals have suffered from unanticipated negative health events or not. As it can be seen here, on average experience significantly increases intentions to purchase income protection insurance in all countries.
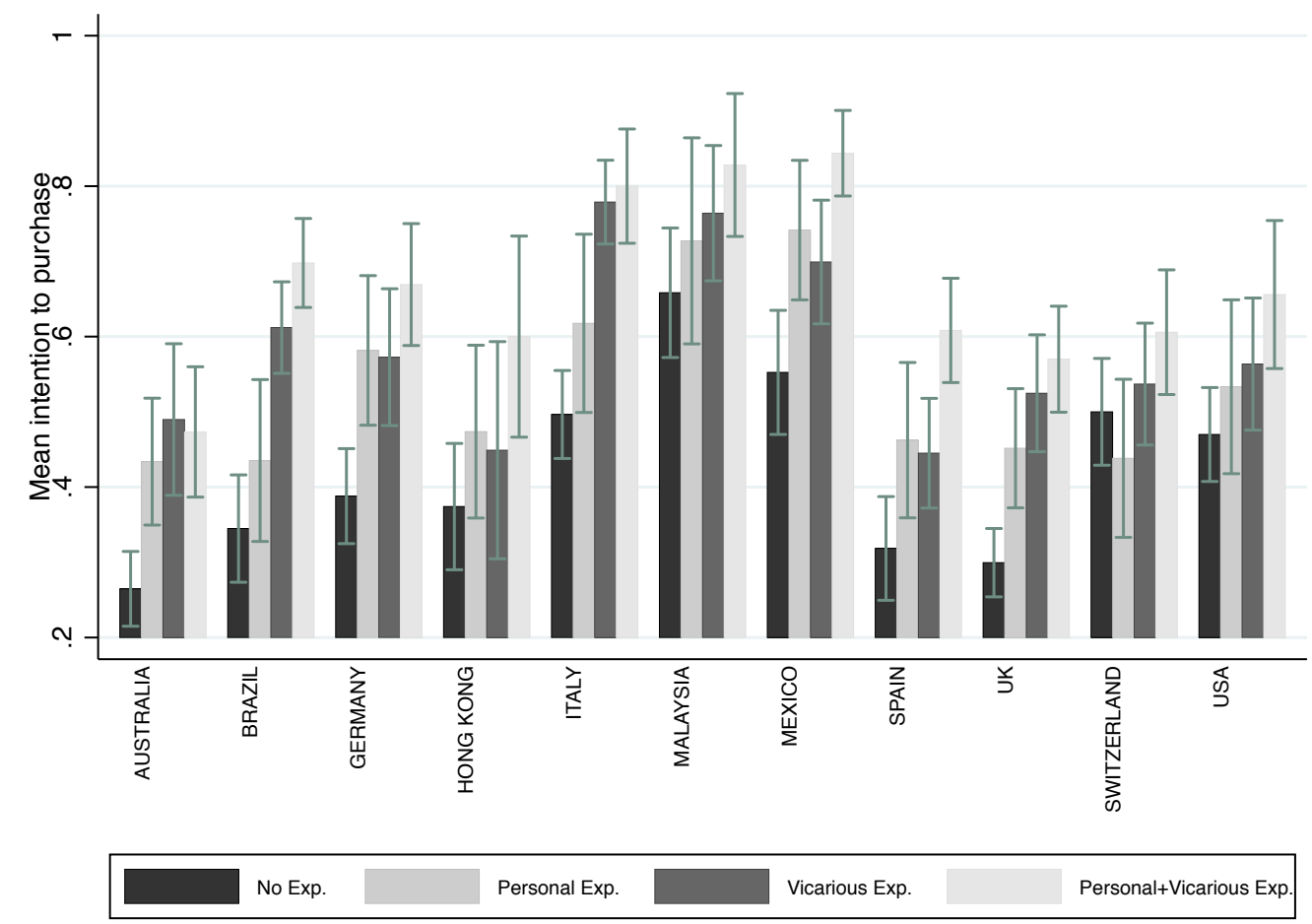

Notes: The error bars reported follow a $95 \%$ confidence interval.

Figure 1: Mean intention to purchase insurance in each country by experience type

Table 1 also reports other general characteristics of the respondents. Those with positive purchase intentions are younger, more likely to be male, and more likely to have children under 18 as well as a higher number of individuals who rely on their income. While those with positive intentions to purchase are significantly more likely to believe that they will be healthier in the future, there exists no significant 
differences in current health state or personal risk perceptions between those with positive intentions and those with no intention at all. There is no significant difference between the two groups in terms of education or financial literacy. Individuals who report an intention to purchase are also significantly more risk averse.

Table 1: Summary Statistics

\begin{tabular}{l|l|lll}
\hline & $\begin{array}{l}\text { Full Sample } \\
\text { Mean } \%\end{array}$ & $\begin{array}{l}\text { No intention } \\
\text { Mean } \%\end{array}$ & $\begin{array}{l}\text { Intention } \\
\text { Mean } \%\end{array}$ & $\begin{array}{c}\text { Difference } \\
\text { in Means } \\
\text { T-test }\end{array}$ \\
\hline Intention to purchase insurance & $52.7 \%$ & & & \\
Experience (personal+vicarious) & $62.9 \%$ & $53.1 \%$ & $71.7 \%$ & $-15.73^{* * *}$ \\
Personal experience & $38.8 \%$ & $32.5 \%$ & $44.4 \%$ & $-9.92^{* * *}$ \\
Vicarious experience & $47.3 \%$ & $37.2 \%$ & $56.4 \%$ & $-15.73^{* * *}$ \\
Personal risk & 2.52 & 2.37 & 2.65 & $-5.86^{* * *}$ \\
Better than avg. health & $24.1 \%$ & $24.8 \%$ & $23.4 \%$ & 1.34 \\
Future health better than now & $26.2 \%$ & $24.9 \%$ & $27.4 \%$ & $-2.36^{*}$ \\
& & & & \\
Age (years) & 41.9 & 43.3 & 40.6 & $10.69^{* * *}$ \\
Male & $45.5 \%$ & $44.7 \%$ & $46.3 \%$ & -1.33 \\
Children $<18$ & $35.2 \%$ & $28.2 \%$ & $41.4 \%$ & $-11.21^{* * *}$ \\
\# of people rely on income & 1.89 & 1.75 & 2.01 & $-9.29^{* * *}$ \\
Current income $\leq 25$ th percentile & $39.2 \%$ & $43 \%$ & $35.80 \%$ & $5.95^{* * *}$ \\
Current income $\geq 75$ th percentile & $23.9 \%$ & $20 \%$ & $27.50 \%$ & $-7.16^{* * *}$ \\
Employee & $79.2 \%$ & $79 \%$ & $79.30 \%$ & -0.30 \\
& & & & \\
Financial Literacy (Score) & 1.97 & 1.96 & 1.98 & -0.52 \\
Education (years of) & 14.6 & 14.6 & 14.7 & -0.34 \\
Risk aversion & 3.64 & 3.88 & 3.42 & $14.72^{* * *}$ \\
$\mathrm{~N}$ & 6481 & 3066 & 3415 & \\
\hline$*$ p $<0.05, * *$ p $<0.01, * * *$ p $<0.001$ & & & & \\
& &
\end{tabular}

In Appendix A we report additional information on the sample characteristics. In table A.3 we specifically report the number of individuals who expressed an intention to purchase income protection insurance in the future and those who did not for each country in our sample. We also report this same information for each occupation. We also report the Pearson's correlation coefficients amongst all regressors included 
in our analysis in table A.4. ${ }^{2}$

\section{Results}

In order to test our main conjecture, we start by analysing the impact of experience on the intention to purchase an income protection policy. We report our results in table 2. The first column reports the estimates of our basic logit specification where we include only first- and second-hand experience and our set of controls. Having had a negative health experience in the past increases the probability of stating the intention to purchase an insurance policy by 0.11 , translating into a $25 \%$ increase from the baseline probability of 0.41 . The baseline probability refers to the average probability keeping both personal and vicarious experiences fixed at zero. We will continue to use this definition of the baseline probability throughout the rest of the empirical section. Knowing instead somebody who suffered from negative health events in the past increases the intention to purchase insurance by 0.17 or by 40\%. This confirms Robertson et al.'s (1972) findings, according to which the experience of others is considered in one's own decision to adopt preventive behaviour. An individual who has been ill in the past and also knows someone who has is $48 \%$ more likely to express a positive intention to purchase insurance than someone who has neither type of experience.

In the second column we consider both experience and risk perceptions. Both coefficients are highly significant and the inclusion of individual risk perceptions

\footnotetext{
${ }^{2}$ In general, all correlation coefficients are very low and there are no strong linear dependencies among the explanatory variables. Additionally, as a post estimation for multicollinearity, we relied on the "variance inflation factor" (VIF) and tolerance for individual predictors. As a rule of thumb, a variable whose VIF values are greater than 10 and whose tolerance is greater than 0.1 requires further investigation. According to our analysis, all our VIFs are below 10 and the tolerance values are lower than 0.1 suggesting no strong linear relationship among the predictors.
} 
Table 2: The effect of personal and vicarious experience on intention to purchase insurance

\begin{tabular}{|c|c|c|c|c|c|c|}
\hline & \multicolumn{6}{|c|}{ Intention to purchase insurance } \\
\hline & \multicolumn{4}{|c|}{ Full sample } & \multirow{2}{*}{$\begin{array}{l}\text { Above median } \\
\text { income } \\
(5)\end{array}$} & \multirow{2}{*}{$\begin{array}{c}\text { Full sample } \\
(6)\end{array}$} \\
\hline & (1) & (2) & (3) & (4) & & \\
\hline Personal Experience & $\begin{array}{c}0.474^{* * *} \\
(0.057)\end{array}$ & $\begin{array}{c}0.452^{* * *} \\
(0.059)\end{array}$ & $\begin{array}{c}0.449^{* * *} \\
(0.059)\end{array}$ & $\begin{array}{c}0.445^{* * *} \\
(0.058)\end{array}$ & $\begin{array}{c}0.586^{* * *} \\
(0.070)\end{array}$ & $\begin{array}{c}0.444^{* * *} \\
(0.058)\end{array}$ \\
\hline Vicarious Experience & $\begin{array}{c}0.740 * * * \\
(0.091)\end{array}$ & $\begin{array}{c}0.724^{* * *} * \\
(0.088)\end{array}$ & $\begin{array}{c}0.723^{* * *} \\
(0.088)\end{array}$ & $\begin{array}{c}0.723^{* * *} \\
(0.088)\end{array}$ & $\begin{array}{c}0.729^{* * *} \\
(0.067)\end{array}$ & $\begin{array}{c}0.708^{* * *} \\
(0.087)\end{array}$ \\
\hline Personal risk & & $\begin{array}{l}0.045^{*} \\
(0.018)\end{array}$ & $\begin{array}{l}0.042^{*} \\
(0.018)\end{array}$ & $\begin{array}{l}0.042^{*} \\
(0.018)\end{array}$ & $\begin{array}{l}0.043^{*} \\
(0.022)\end{array}$ & $\begin{array}{l}0.045^{*} \\
(0.018)\end{array}$ \\
\hline $\begin{array}{l}\text { Better than } \\
\text { avg. health }\end{array}$ & & & -0.126 & -0.118 & $-0.315^{* *}$ & $-0.143^{*}$ \\
\hline & & & $(0.067)$ & $(0.065)$ & $(0.115)$ & $(0.064)$ \\
\hline Higher future health & & & & $\begin{array}{c}0.080 \\
(0.102)\end{array}$ & $\begin{array}{c}0.102 \\
(0.160)\end{array}$ & $\begin{array}{c}0.069 \\
(0.102)\end{array}$ \\
\hline Male & $\begin{array}{c}0.052 \\
(0.038)\end{array}$ & $\begin{array}{c}0.052 \\
(0.037)\end{array}$ & $\begin{array}{c}0.054 \\
(0.037)\end{array}$ & $\begin{array}{c}0.055 \\
(0.038)\end{array}$ & $\begin{array}{c}0.126 \\
(0.074)\end{array}$ & $\begin{array}{c}0.054 \\
(0.037)\end{array}$ \\
\hline Age & $\begin{array}{c}-0.026^{* * *} \\
(0.004)\end{array}$ & $\begin{array}{c}-0.027^{* * *} \\
(0.004)\end{array}$ & $\begin{array}{c}-0.027^{* * *} \\
(0.004)\end{array}$ & $\begin{array}{c}-0.027^{* * *} \\
(0.004)\end{array}$ & $\begin{array}{c}-0.028^{* * *} \\
(0.005)\end{array}$ & $\begin{array}{c}-0.025^{* * *} \\
(0.004)\end{array}$ \\
\hline $\begin{array}{l}\text { \# people } \\
\text { rely on income }\end{array}$ & $0.072^{*}$ & $0.069^{*}$ & $0.069^{*}$ & $0.069^{*}$ & 0.045 & $0.068^{*}$ \\
\hline & $(0.033)$ & $(0.032)$ & $(0.032)$ & $(0.032)$ & $(0.043)$ & $(0.033)$ \\
\hline children $<18$ & $\begin{array}{c}0.356^{* * *} \\
(0.075)\end{array}$ & $\begin{array}{c}0.352^{* * *} \\
(0.076)\end{array}$ & $\begin{array}{c}0.351^{* * * *} \\
(0.077)\end{array}$ & $\begin{array}{c}0.352^{* * *} \\
(0.077)\end{array}$ & $\begin{array}{c}0.347^{* *} \\
(0.108)\end{array}$ & $\begin{array}{c}0.348^{* * *} \\
(0.079)\end{array}$ \\
\hline $\begin{array}{r}\text { Education } \\
\text { (vears of) }\end{array}$ & -0.004 & -0.004 & -0.003 & -0.003 & 0.008 & -0.004 \\
\hline & $(0.006)$ & $(0.006)$ & $(0.006)$ & $(0.006)$ & $(0.010)$ & $(0.006)$ \\
\hline $\begin{array}{l}\text { Bottom } 25 \% \text { of } \\
\text { current income }\end{array}$ & $-0.306^{* * *}$ & $-0.316^{* * *}$ & $-0.317^{* * *}$ & $-0.318^{* * *}$ & & $-0.317^{* * *}$ \\
\hline & $(0.071)$ & $(0.070)$ & $(0.069)$ & $(0.070)$ & & $(0.070)$ \\
\hline $\begin{array}{r}\text { Top } 25 \% \text { of } \\
\text { current income }\end{array}$ & $0.354^{* * *}$ & $0.357^{* * *}$ & $0.364^{* * *}$ & $0.365^{* * *}$ & 0.008 & $0.352^{* * *}$ \\
\hline & $(0.073)$ & $(0.072)$ & $(0.071)$ & $(0.071)$ & $(0.084)$ & $(0.073)$ \\
\hline Employee & $\begin{array}{c}0.030 \\
(0.105)\end{array}$ & $\begin{array}{c}0.031 \\
(0.106)\end{array}$ & $\begin{array}{c}0.023 \\
(0.108)\end{array}$ & $\begin{array}{c}0.025 \\
(0.107)\end{array}$ & $\begin{array}{l}-0.127 \\
(0.200)\end{array}$ & $\begin{array}{c}0.035 \\
(0.108)\end{array}$ \\
\hline Higher future income & & & & & & $\begin{array}{c}0.239^{* *} \\
(0.056)\end{array}$ \\
\hline Constant & $\begin{array}{l}-0.170 \\
(0.292)\end{array}$ & $\begin{array}{l}-0.227 \\
(0.299)\end{array}$ & $\begin{array}{l}-0.183 \\
(0.311)\end{array}$ & $\begin{array}{l}-0.239 \\
(0.288)\end{array}$ & $\begin{array}{c}0.031 \\
(0.422)\end{array}$ & $\begin{array}{l}-0.347 \\
(0.287)\end{array}$ \\
\hline $\begin{array}{r}\text { Country } \\
\text { dummies }\end{array}$ & Yes & Yes & Yes & Yes & Yes & Yes \\
\hline $\begin{array}{r}\text { Occupation } \\
\text { dummies }\end{array}$ & Yes & Yes & Yes & Yes & Yes & Yes \\
\hline $\mathrm{N}$ & 6001 & 6001 & 6001 & 6001 & 1919 & 6001 \\
\hline $\mathrm{BIC}$ & 7544 & 7536 & 7533 & 7531 & 2370 & 7517 \\
\hline Pseudo $R^{2}$ & 0.10 & 0.10 & 0.10 & 0.10 & 0.11 & 0.10 \\
\hline
\end{tabular}

Notes: Unstandardised coefficients of logistic regressions. Robust standard errors in parenthesis. Standard errors clustered at the country level, ${ }^{*} \mathrm{p}<0.05,{ }^{* *} \mathrm{p}<0.01,{ }^{* * *} \mathrm{p}<0.001$. 
does not drastically reduce the importance of experience. Having personally had a negative health experience in the past continues to increase the probability of considering the purchase of insurance by roughly $24 \%$ compared to the baseline, whereas knowing somebody who has suffered from ill health increases intentions to purchase insurance from 0.42 to 0.58 , i.e. by about $39 \%$.

In the third column of table 2 we include an additional indicator variable which is equal to one if individuals believe themselves be healthier than average and zero otherwise. Interestingly, individuals who claim to be healthier are significantly less likely to purchase insurance than those who feel less than or as healthy as the average. The inclusion of this indicator leaves the coefficients of experience basically unchanged. In column 4 of table 2 we insert a dummy to control for optimistic expectations regarding future health. This indicator is equal to one for all those individuals who believe that their health is going to improve in the future. We find no significant relation between health optimism and the intention to purchase insurance. The inclusion of this indicator also reduces the significance of one's self-assessed health status. However, more importantly from our point of view, controlling for higher future health does not affect the coefficients of personal or vicarious experience, which remain both stable and highly significant.

In column 5 of table 2 we show that the effect of experience does not fade away with liquidity. We restrict the sample only to those individuals whose current income is above the country median and we find that the effect of both types of experience is similar in magnitude to that for the large sample. This simply shows that experience matters even for richer people who decide to buy insurance to protect themselves against income losses even if their current income makes them, in principle, less economically vulnerable to unexpected negative health events. Last, in column 6 of table 2 we show that the effect of experience remains stable even when controlling 
for positive expectations of income growth. We include in this regression a dummy variable which takes value one for all individuals who foresee that their income is likely to increase compared to its current level. Indeed, positive expectations about one's future income significantly increase people's intentions to purchase income protection policies. However, this effect does not supplant in any way the role played by personal or vicarious experience. ${ }^{3}$

In summary, table 2 suggests that past health experience, be it personal or vicarious, is a strong driver behind individuals' intention to purchase income protection insurance, providing strong support for our hypothesis. Remarkably, it is also shown that knowing someone who has in the past suffered from ill health exerts a stronger effect on intentions to purchase than personal experience does. This strong relationship suggests that, on the one hand, intentions to purchase might be rooted into the salience and vividness of the experience potentially of others and not only on its informativeness concerning one's vulnerability. On the other hand, this relationship could be explained by the fact that, when intending to buy income protection insurance, individuals do not have to provide details of the health history of their peers, whereas they are obliged to disclose their own. The latter can result in to denial of coverage or an increase in the premium. As a consequence, vicarious experience does not act as an obstacle to seeking coverage in the way that personal experience does. Interestingly, our results are stable also for those individuals whose income exceeds their country median. Wealthier individuals are in principle less vulnerable to income

\footnotetext{
${ }^{3}$ In Appendix B table B.5 we provide a breakdown of personal experience into physical and emotional experience. We show that there exists no substitution effect among physical, emotional and vicarious experience. The three types of experience are simultaneous significant predictors of intentions to purchase insurance. In addition, we also tested for the explanatory power of interaction terms between personal and vicarious experience. While there seems to be diminishing return to having both types of experiences, the interaction effect lacks statistical significance in any of the specifications presented in table 2 , and did not increase the predictive power to the models.
} 
interruptions and potentially less inclined to adopt self-protective measures. Effectively though past negative experiences offer a counterfactual and trigger emotional reactions which transcend cognitive evaluations (Loewenstein et al., 2001). Additionally, table 2 shows that older individuals are less likely to state they will purchase insurance, whereas those who have a higher number of dependents or underaged children are (generally) significantly more likely to consider purchasing insurance in the future. We do not find any evidence for a gender effect on intentions to purchase insurance. Being an employee also does not affect intentions to purchase insurance in a significant manner. Generally, those who see themselves as being at risk of losing income for unexpected health reasons are significantly more inclined toward the rational decision to buy income protection insurance.

\section{Robustness checks}

We conducted multiple of robustness checks to determine the solidity of our results. In section 6.1 we account for the severity and timing of personal experience. In section 6.2, we wish to ascertain that the effect of first- or second-hand experience is not undermined when controlling for risk aversion, insurance knowledge, or financial literacy. Additionally, to further our understanding of possible countries differences, we revert to country-specific models in section 6.3. Finally, in section 6.4 we explore the effect of past experience on actual insurance ownership to account for a potential 'planning-behaviour gap'. Details on the regressions results are confined to Appendix B, in the text below we report the main findings.

\subsection{Severity, length and recency of personal experience}

The analysis conducted above did not discern between severe and less severe past negative experiences, nor did it discriminate between events which occurred in 
the distant past from those happened more recently. However, previous literature showed that the recency and seriousness of the experience matter (Malmendier \& Nagel, 2011; Bucciol \& Zarri, 2015). For these reasons, we address the issue and run three separate models which account for the severity, length, and recency of experience.

Our key estimates are reported in Figure B.2 in Appendix B wherein we first consider the effect that serious events (such as a stroke, cancer, heart attack) and all other diseases (including mental health issues) separately may play on intentions to insure oneself. We also evaluate whether the respondent was out of work for a short period of time or for 6 months or more (protracted). To account for the timing of the experience, using question 14, we evaluate whether the negative health event has occurred recently or in the past i.e. 6 months prior to the survey or earlier.

As it can be seen, the effect of experience on the intention to purchase insurance is relatively stable. More extreme events, protracted illnesses as well as more recent episodes of ill health do not strengthen the effect of experience on purchasing intentions. Insurance purchasing intentions are not driven by cardiovascular diseases or neoplasms. This is in line with the fact that serious pre-existing conditions must be disclosed when applying for insurance policies. Serious negative health events are likely to increase the premium to be paid or even result into a denial of the coverage. As a result, this frustrates intentions.

\subsection{Risk aversion, insurance knowledge, financial literacy and experience}

Another possible criticism to the analysis we conducted above concerns the omission of a measure of attitudes towards financial risk. On the one hand, risk tolerance could directly affect the likelihood of adopting of self-protective measures (Mol et al., 2018). On the other hand, risk attitudes could affect the extent to which one is ex- 
posed to experience.

Although part of this effect should be captured by the coefficient of personal risk which identifies self-perceptions about the probabilities of losing income due to ill health, we explore this conjecture further. The measure of risk aversion we use consists of answers to one of the survey questions which asked participants whether, when making investments, they are willing to take substantial, above average, average, low, or no risk at all. ${ }^{4}$

We also wish evaluate the role of insurance knowledge and general financial abilities as they might both affect the role that experience plays on intentions to purchase insurance. In fact, it could a priori be argued that experience, be it first- or secondhand, might not be relevant at all, if the agent has low knowledge of insurance. Additionally, more financially skilled individuals might react differently from less skilled ones when evaluating the intrinsic information that experience can provide and ultimately form intentions to purchase insurance. Lusardi \& Mitchell (2014) have in fact in multiple instances asserted that high levels of financial literacy help people in making sound financial decisions (Lusardi \& Mitchell, 2014, 2007). To mea-

\footnotetext{
${ }^{4}$ This question is based on a regular survey item included in the US Survey of Consumer Finance and has been used in previous studies (Malmendier \& Nagel, 2011; Guiso et al., 2018; Kettlewell, 2019). As numerous scholars have debated, the key question is whether self-reported measures like ours are valid measures of risk preferences (see Pedroni et al. (2017); Mata et al. (2018) for detailed reviews on the topic). Inattention and self-serving biases could in fact lead respondents to report distorted financial risk attitudes. However, Dohmen et al. (2011) suggest that stated risk attitudes generate results that are compatible with those obtained in experimental settings. Vieider et al. (2015) measured risk through incentivised measures as well as survey questions in 30 countries. Their results confirm that survey results correlate with incentivised measures. Frey et al. (2017) claim that stated measures show higher test-retest reliability than experimental measures. Furthermore, at stake is whether eliciting general risk-preference informs about context specific risk tolerance. Dohmen et al. (2011) claim that questions tailored to specific contexts provide a stronger measure of risk attitudes within those particular domains. This evidence suggests that the question included in our survey is likely to capture financial risk taking better than a more general question, and as our objective is to examine long-term financial planning, this appears to be a suitable measurement method.
} 
sure insurance knowledge, we rely on answers to a question which asked individuals to report their degree of knowledge about income protection insurance. Financial literacy levels are evaluated using the number of correct answers to the standard financial literacy test elaborated by Lusardi \& Mitchell (2014).

We report the results of our estimates, including the interaction terms, in table B.6 in Appendix B and conclude that experience significantly increases intentions to acquire insurance, even after controlling for individual risk aversion, insurance knowledge, or financial literacy. These factors have overall a significant impact on intentions to purchase insurance, but their effects are additional to that played by personal and vicarious experience.

The effect that first- or second-hand experience exerts on the intentions to purchase insurance seems to be independent from individual risk-tolerance. Moreover, the effect of experience on the intentions to purchase insurance is the same at all levels of risk tolerance, as shown by the non-significant interaction terms.

Holding knowledge about insurance is likely to increase individuals' intention to buy a policy, but the effect of experience is not curtailed. Independently from peoples' knowledge levels, the effect of experience remains quite stable and strongly significant.

Additionally, first- and second-hand experience are significant predictors of insurance purchase intentions even when we control for financial literacy levels. But whereas the effect of personal experience on intentions to purchase insurance is the same at all levels of financial literacy, vicarious experience matters less for highly financially literate individuals and, for every unit increase in the financial literacy test score, the effect of second-hand experience decreases its power. ${ }^{5}$

\footnotetext{
${ }^{5}$ To be even more precise, whereas, ceteris paribus, for financially illiterate individuals, vicarious
} 


\subsection{The effect of experience across countries}

Previous literature has stressed that finding a positive correlation between precautionary intentions and experience might simply indicate greater exposure to risks in some countries than in others, rather than the effect of experience per se (Weinstein, 1989). For this reason, country fixed effects are included in all our regressions to remove the impact on the intention to purchase insurance of fixed country characteristics which are potentially correlated with experience. ${ }^{6}$ However, we also ran country level regressions to possibly identify differences on the effect that either type of experience plays on intentions to buy insurance.

These results are reported in figure B.3 in Appendix B wherein we show that experience generally affects intentions to purchase insurance in a positive manner in all countries. However, this effect differs in magnitude and significance depending on the country under scrutiny. Vicarious experience significantly increases purchasing intentions in all countries except Hong Kong. Its effect is stronger in Italy, Brazil and Malaysia. The effect of personal experience varies, and despite being positive in all 11 countries it does not significantly affect intentions to purchase insurance in Italy, Malaysia, Switzerland, and the US. As the large error bars suggest, this might be due to a lack of precision and thus power when splitting the data by country. Nonetheless, the large differences observed in figure B.3 could be also due to country-specific welfare regimes. When deciding to purchase insurance, people might in fact weight peers' experience differently depending on the country's welfare

experience increases the probability of uptake by $53 \%$ (i.e. from 0.37 to 0.56 ), for financially skilled people the experience of peers increases the probability of uptake by $32 \%$ (i.e. from 0.45 to 0.59 ).

${ }^{6} \mathrm{~A}$ one-way ANOVA was conducted in the first instance to determine whether the intention to hold income protection insurance differed by country of residence. According to our results, there are statistically significant differences between countries as determined by one-way ANOVA $(\mathrm{F}(10,6481)=29.99, \mathrm{p}<0.000)$. Additionally, a chi-squared test on the experience (both personal and vicarious) data finds significant differences among countries $\left(\chi^{2}(10)=173,22 \operatorname{Pr}=0.000\right)$. 
system. $^{7}$

\subsection{Experience and insurance ownership}

As a last robustness check, we wish to investigate the possible existence of a 'planning-behaviour gap'. Previous literature suggests that whereas past negative events exert a positive effect on self-reported future intentions, agents might underweight the importance of both personal and vicarious experience when actually purchasing insurance policies (Yechiam et al., 2005, 2006). For this reason, we estimate the effect of prior experience on actual behaviour, i.e. insurance ownership which we evaluate using question 6 in our survey. ${ }^{8}$ Indeed, as mentioned, this part of the analysis cannot be deemed to be conclusive. Our econometric identification strategy is further weakened as we cannot assume that the insurance policy was purchased in the aftermath of a past personal or vicarious negative event.

However, the results presented in table B.7 in Appendix B serve to mitigate the concern of a planning-behaviour gap as they suggest that there exists a positive and significant correlation between income protection insurance ownership and personal or vicarious experience. Keeping all other factors fixed, the probability of buying an insurance policy for somebody who has personally experienced a loss of income in

\footnotetext{
${ }^{7}$ Over the last 25 years, social scientists have debated the importance of nation-state regimes in the welfare provision process concluding that countries matter. Different welfare states give rise to heterogeneous institutions, policy instruments and practices (Esping-Andersen, 1990, 1999; Rodrik, 2013; Badarinza et al., 2016) including those related to income protection and benefit provision in case of income loss. As a consequence, depending on the country they live in, individuals have different expectations on whether the state will shoulder their potential income loss. Our possible interpretation of these results here is that vicarious experience counts for more in countries where social safety nets are not perceived to be strong or reliable by the public.

${ }^{8}$ Note that while the survey question on intentions was limited to individuals without income insurance, the survey item enquiring about ownership of income protection insurance has been answered by the entire sample. This significantly increases to around 10000 the number of individuals included the empirical models.
} 
the past due to health reasons is 0.35 , around $23 \%$ higher than the probability for those who did not have this negative experience. The effect of vicarious experience is only slightly stronger. It raises the probability of insurance ownership by $31 \%$ compared to baseline probability of $0.29 .^{9}$

Although no definitive conclusion can be drawn from this, our result seems to suggest that experience affects not only intentions but also behaviour. However, past events seem to exert a stronger effect on purchasing intentions rather than ownership. Additionally, vicarious experience seems to matter more than personal health vicissitudes, suggesting that the experience of others has a larger effect. Observing others' experience strongly determines one's own planning strategies, but its effect on actual actions is smaller. Conversely, the effect exerted by personal experience is relatively stable independently of whether intentions or actual ownership are evaluated.

\section{Discussion}

The decision to purchase income protection insurance is an inter-temporal choice under risk and uncertainty which is difficult to rationalise using simple utilitymaximising conjectures, as previous research has shown. This paper contributes to the literature by investigating whether and to what extent first- and second-hand experience of losses in earned income due to illness or disability affects individuals' future intentions to purchase income protection insurance.

We find strong support for our hypothesis: Having personally suffered from health adversities which prevented individuals from working, or knowing somebody who has, significantly increases one's intention to purchase insurance compared to the

\footnotetext{
${ }^{9}$ When also considering self-perceived risk of income loss, as reported in model 2 in table B.7, personal experience increases the probability of uptake by $22 \%$, whereas vicarious experience by $29 \%$.
} 
baseline. Ceteris paribus, having personally suffered from ill health and lost income in the past increases the intention to purchase income protection insurance by $25 \%$. Conversely, the experience of others increases one's intentions to buy insurance by 40\%. These results are robust across model specifications. The effect of personal experience is stable even when considering its severity, length, and recency. The role of first- and second-hand experience is also independent of other confounding factors such as individuals' risk aversion, insurance knowledge or financial literacy. The effect is also relatively solid across countries. Furthermore, our analysis shows that past experience, be it first- or second-hand, is positively correlated with actual insurance ownership suggesting that experience matters even when looking at actual behaviour. However, it exerts a stronger effect on intentions than on ownership.

In general, our result confirms that of Tennyson \& Yang (2014) who stated that past experience affects intentions to purchase long-term care insurance. However, an open question in the literature on experience regards the micro-mechanism behind this relationship. Is experience a simple source of information or a trigger for an emotional reaction? Our study takes a step towards a more conclusive answer.

Our results show that in the context of intentions to purchase income protection insurance, experience is not just another variable "that is inserted into a decision equation" (Weinstein, 1989, p.47). Rather, available experience, especially of others, is likely to affect intentions and fuel self-protective actions possibly because it elicits affective reactions (Weber, 2006). Knowing somebody who has in the past suffered from ill health exerts a stronger effect on intentions to purchase than personal experience does.

This strong relationship, on the one hand, suggests that intentions to purchase might be rooted into the salience and vividness of the experience of others and not only on its informativeness concerning one's vulnerability. The vividness of peers' 
experience and the strength of anticipatory emotions (Loewenstein et al., 2001) seem to represent some of the key motivations behind uptake. On the other hand, people might give more weight to others simply because, when intending to buy income protection insurance, individuals do not have to provide details of the health history of their peers, whereas they are obliged to disclose their own. The latter can result in to denial of coverage, or simple increase in the premium. As a consequence, vicarious experience does not act as an obstacle to seeking coverage in the way that personal experience does.

The positive relationship between experience and intentions generally holds for the majority of the 11 countries which make up the respondent base of our survey. As mentioned, however, its significance varies depending on the respondent's country of residence. But, as our sample relies on working individuals who have potentially suffered from ill health or know somebody who has, we may well have identified a fundamental behavioural trait given that our results do not suffer from the possible biases which arise when testing for behaviour across cultures using university test subjects (Henrich et al., 2010).

Our study is not without limitations. As mentioned, our dataset does not offer information on participants' personality traits which could impact the likelihood of suffering from ill health through a specific lifestyle, choosing a specific occupation or holding a positive intention to purchase insurance. Testing whether the effect of experience on intentions holds even when these omitted variables are included would undoubtedly strengthen our results. Additionally, our findings highlight the importance of vicarious experience on insurance purchasing intentions. However, the data in our possession does not allow us to control for either the degree of social connections, nor for the seriousness of the experience of others. In particular, given that we only ask whether respondents personally know someone who has experienced 
health-related income losses, we lack data on whether these acquaintances are family members or otherwise. In the former case, it is rational that vicarious experience leads to positive intentions to buy insurance given the existence of genetic connections, whereas in the latter case the effects are purely emotional or social. Gathering information on the existence of a possible genetic link between family and on the severity and timing of vicarious experience both represent very interesting avenues for future research.

In spite of the above limitations, we believe that our findings have an important policy implication. As noted above, the impact of experience depends upon being unexpected and being emotionally vivid in effect. The challenge is to explain the salience of some risk that is hitherto unexperienced. However, we know from previous research that warnings are more effective when they rely on emotionally charged anecdotes rather than sterile statistics (Hendrickx et al., 1989). As such, one way of accounting for our results is to design warning campaigns which specifically focus on the salience of events which have happened to others and their likely burdensome consequences (Robinson et al., 2016). These can act as commitment devices and potentially help individuals to overcome their difficulties to correctly assess the risks to which they are exposed. 


\section{References}

Aragones, E., Gilboa, I., Postlewaite, A., \& Schmeidler, D. (2005). Fact-free learning. American Economic Review, 95, 1355-1368.

Badarinza, C., Campbell, J. Y., \& Ramadorai, T. (2016). International comparative household finance. Annual Review of Economics, 8, 111-144.

Barrick, M. R., \& Mount, M. K. (1991). The big five personality dimensions and job performance: a meta-analysis. Personnel psychology, 44, 1-26.

Barron, G., \& Erev, I. (2003). Small feedback-based decisions and their limited correspondence to description-based decisions. Journal of Behavioral Decision Making, 16, 215-233.

Bernile, G., Bhagwat, V., \& Rau, P. R. (2017). What doesn't kill you will only make you more risk-loving: Early-life disasters and ceo behavior. The Journal of Finance, 72, 167-206.

Bhattacharya, J., Goldman, D., \& Sood, N. (2009). Market evidence of misperceived mortality risk. Journal of Economic Behavior \& Organization, 72, 451-462.

Brown, R., \& Kulik, J. (1977). Flashbulb memories. Cognition, 5, 73-99.

Bucciol, A., \& Zarri, L. (2015). The shadow of the past: Financial risk taking and negative life events. Journal of Economic Psychology, 48, 1-16.

Burling, T. A., Singleton, E. G., Bigelow, G. E., Baile, W. F., \& Gottieb, S. H. (1984). Smoking following myocardial infarction: a critical review of the literature. Health Psychology, 3, 83-96. 
Christopherson, S. (2002). Project work in context: regulatory change and the new geography of media. Environment and Planning A, 34, 2003-2015.

Curry, L. A., Robison, J., Shugrue, N., Keenan, P., \& Kapp, M. B. (2009). Individual decision making in the non-purchase of long-term care insurance. The Gerontologist, 49, 560-569.

Cutler, D. M., \& Zeckhauser, R. (2004). Extending the theory to meet the practice of insurance. Brookings-Wharton Papers on Financial Services, 2004, 1-53.

Dohmen, T., Falk, A., Huffman, D., Sunde, U., Schupp, J., \& Wagner, G. G. (2011). Individual Risk Attitudes: Measurement, Determinants, and Behavioral Consequences. Journal of the European Economic Association, 9, 522-550.

Erev, I., Ert, E., Plonsky, O., Cohen, D., \& Cohen, O. (2017). From anomalies to forecasts: Toward a descriptive model of decisions under risk, under ambiguity, and from experience. Psychological Review, 124, 369-409.

Esping-Andersen, G. (1990). The three worlds of welfare capitalism. Princeton: Princeton University Press.

Esping-Andersen, G. (1999). Social foundations of postindustrial economies. Oxford: Oxford University Press.

Frey, R., Pedroni, A., Mata, R., Rieskamp, J., \& Hertwig, R. (2017). Risk preference shares the psychometric structure of major psychological traits. Science Advances, 3, e1701381.

Gallagher, J. (2014). Learning about an infrequent event: evidence from flood insurance take-up in the United States. American Economic Journal: Applied Economics, 6, 206-33. 
Garofalo, J. (1977). Public opinion about crime: The attitudes of victims and nonvictims in selected cities volume 1. US Department of Justice, Law Enforcement Assistance Administration, National Criminal Justice Information and Statistics Service.

Guiso, L., Sapienza, P., \& Zingales, L. (2018). Time varying risk aversion. Journal of Financial Economics, 128, 403-421.

Hamill, R., Wilson, T. D., \& Nisbett, R. E. (1980). Insensitivity to sample bias: Generalizing from atypical cases. Journal of Personality and Social Psychology, $39,578-589$.

Hendrickx, L., Vlek, C., \& Oppewal, H. (1989). Relative importance of scenario information and frequency information in the judgment of risk. Acta Psychologica, 72, 41-63.

Henrich, J., Heine, S. J., \& Norenzayan, A. (2010). Most people are not weird. Nature, 466, 29.

Hertwig, R., Barron, G., Weber, E. U., \& Erev, I. (2004). Decisions from experience and the effect of rare events in risky choice. Psychological Science, 15, 534-539.

Hertwig, R., \& Erev, I. (2009). The description-experience gap in risky choice. Trends in Cognitive Sciences, 13, 517-523.

Hirsh, J. B., \& Inzlicht, M. (2008). The devil you know: Neuroticism predicts neural response to uncertainty. Psychological Science, 19, 962-967.

ILO (2017). World Social Protection Report 2017-19: Universal social protection to achieve the Sustainable Development Goals. Geneva: International Labour Office. 
Kettlewell, N. (2019). Risk preference dynamics around life events. Journal of Economic Behavior \&3 Organization, 162, 66-84.

Kim, Y.-I., \& Lee, J. (2014). The long-run impact of a traumatic experience on risk aversion. Journal of Economic Behavior \&3 Organization, 108, 174-186.

Kunreuther, H. (1996). Mitigating disaster losses through insurance. Journal of Risk and Uncertainty, 12, 171-187.

Kunreuther, H., \& Michel-Kerjan, E. (2015). Demand for fixed-price multi-year contracts: Experimental evidence from insurance decisions. Journal of Risk and Uncertainty, 51, 171-194.

Kunreuther, H., \& Pauly, M. (2004). Neglecting disaster: why don't people insure against large losses? Journal of Risk and Uncertainty, 28, 5-21.

Kunreuther, H. C., Pauly, M. V., \& McMorrow, S. (2013). Insurance and behavioral economics: Improving decisions in the most misunderstood industry. Cambridge: Cambridge University Press.

Loewenstein, G., O'Donoghue, T., \& Rabin, M. (2003). Projection bias in predicting future utility. The Quarterly Journal of Economics, 118, 1209-1248.

Loewenstein, G. F., Weber, E. U., Hsee, C. K., \& Welch, N. (2001). Risk as feelings. Psychological Bulletin, 127, 267-286.

Lusardi, A., \& Mitchell, O. S. (2007). Financial literacy and retirement preparedness: Evidence and implications for financial education. Business Economics, 42, 35-44.

Lusardi, A., \& Mitchell, O. S. (2014). The economic importance of financial literacy: Theory and evidence. Journal of Economic Literature, 52, 5-44. 
Lusardi, A., Schneider, D. J., \& Tufano, P. (2011). Financially fragile households: Evidence and implications. Technical Report National Bureau of Economic Research Working Paper.

Maguire, M. (1980). The impact of burglary upon victims. British Journal of Criminology, 20, 261-275.

Malmendier, U., \& Nagel, S. (2011). Depression babies: do macroeconomic experiences affect risk taking? The Quarterly Journal of Economics, 126, 373-416.

Marx, S. M., Weber, E. U., Orlove, B. S., Leiserowitz, A., Krantz, D. H., Roncoli, C., \& Phillips, J. (2007). Communication and mental processes: Experiential and analytic processing of uncertain climate information. Global Environmental Change, 17, 47-58.

Mata, R., Frey, R., Richter, D., Schupp, J., \& Hertwig, R. (2018). Risk preference: A view from psychology. Journal of Economic Perspectives, 32, 155-72.

Michel-Kerjan, E. O. (2010). Catastrophe economics: the national flood insurance program. Journal of Economic Perspectives, 24, 165-86.

Mol, J. M., Botzen, W. W., \& Blasch, J. E. (2018). Behavioral motivations for selfinsurance under different disaster risk insurance schemes. Journal of Economic Behavior \&3 Organization, 24, 483-490.

Nisbett, R. E., Borgida, E., Crandall, R., \& Reed, H. (2004). Popular induction: Information is not necessarily informative. In D. Kahneman, P. Slovic, \& A. Tversky (Eds.), Judgment under uncertainty (pp. 101-116). Cambridge: Cambridge University Press. 
Nisbett, R. E., \& Ross, L. (1980). Human inference: Strategies and shortcomings of social judgment. Prentice-Halll, Englewood Cliffs, NJ.

Oster, E., Shoulson, I., Quaid, K., \& Dorsey, E. R. (2010). Genetic adverse selection: Evidence from long-term care insurance and huntington disease. Journal of Public Economics, 94, 1041-1050.

Pauly, M. V. (1990). The rational nonpurchase of long-term-care insurance. Journal of Political Economy, 98, 153-168.

Pedroni, A., Frey, R., Bruhin, A., Dutilh, G., Hertwig, R., \& Rieskamp, J. (2017). The risk elicitation puzzle. Nature Human Behaviour, 1, 803-809.

Puri, M., \& Robinson, D. T. (2007). Optimism and economic choice. Journal of Financial Economics, 86, 71-99.

Robertson, L. S., O'Neill, B., \& Wixom, C. W. (1972). Factors associated with observed safety belt use. Journal of Health and Social Behavior, 13, 18-24.

Robinson, L. A., Viscusi, W. K., \& Zeckhauser, R. J. (2016). Efficient Warnings, Not "Wolf or Rabbit" Warnings. Technical Report HKS Working Paper No. RWP16033.

Rodrik, D. (2013). The Globalization Paradox. Democracy and the Future of the World Economy. New York: WW Norton.

Roth et al. (2017). Global, regional, and national burden of cardiovascular diseases for 10 causes, 1990 to 2015. Journal of the American College of Cardiology, 70, $1-25$.

Rubin, D. C., \& Kozin, M. (1984). Vivid memories. Cognition, 16, 81-95. 
Rustichini, A., DeYoung, C. G., Anderson, J. E., \& Burks, S. V. (2016). Toward the integration of personality theory and decision theory in explaining economic behavior: An experimental investigation. Journal of Behavioral and Experimental Economics, 64, 122-137. Cognitive Abilities and Economic Behavior.

Salgado, J. F. (1998). Big five personality dimensions and job performance in army and civil occupations: A european perspective. Human Performance, 11, 271-288.

Schwarcz, D. (2010). Insurance demand anomalies and regulation. Journal of Consumer Affairs, 44, 557-577.

Slovic, P., Finucane, M., Peters, E., \& MacGregor, D. G. (2002). Rational actors or rational fools: Implications of the affect heuristic for behavioral economics. The Journal of Socio-Economics, 31, 329-342.

Smith, V. L. (1968). Optimal insurance coverage. Journal of Political Economy, 76, $68-77$.

Tennyson, S., \& Yang, H. K. (2014). The role of life experience in long-term care insurance decisions. Journal of Economic Psychology, 42, 175-188.

Tyler, T. R. (1980). Impact of directly and indirectly experienced events: The origin of crime-related judgments and behaviors. Journal of Personality and Social Psychology, 39, 13-28.

Vieider, F. M., Lefebvre, M., Bouchouicha, R., Chmura, T., Hakimov, R., Krawczyk, M., \& Martinsson, P. (2015). Common Components of Risk and Uncertainty Attitudes Across Contexts and Domains: Evidence from 30 Countries. Journal of the European Economic Association, 13, 421-452. 
Weber, E. U. (2006). Experience-based and description-based perceptions of longterm risk: Why global warming does not scare us (yet). Climatic Change, 77, $103-120$.

Weinstein, N. D. (1982). Unrealistic optimism about susceptibility to health problems. Journal of Behavioral Medicine, 5, 441-460.

Weinstein, N. D. (1987). Unrealistic optimism about susceptibility to health problems: Conclusions from a community-wide sample. Journal of Behavioral Medicine, 10, 481-500.

Weinstein, N. D. (1989). Effects of personal experience on self-protective behavior. Psychological Bulletin, 105, 31-50.

WHO (2011). Global status report on noncommunicable diseases 2010. Geneva: World Health Organization.

Yechiam, E., Barron, G., \& Erev, I. (2005). The role of personal experience in contributing to different patterns of response to rare terrorist attacks. Journal of Conflict Resolution, 49, 430-439.

Yechiam, E., Druyan, M., \& Ert, E. (2008). Observing others' behavior and risk taking in decisions from experience. Judgment and Decision Making, 3, 493-500.

Yechiam, E., Erev, I., \& Barron, G. (2006). The effect of experience on using a safety device. Safety Science, 44, 515-522.

Yechiam, E., \& Ert, E. (2007). Evaluating the reliance on past choices in adaptive learning models. Journal of Mathematical Psychology, 51, 75-84. 
Zhou-Richter, T., Browne, M. J., \& Gründl, H. (2010). Don't they care? or, are they just unaware? risk perception and the demand for long-term care insurance. Journal of Risk and Insurance, 77, 715-747.

Zick, C. D., Mathews, C. J., Roberts, J. S., Cook-Deegan, R., Pokorski, R. J., \& Green, R. C. (2005). Genetic testing for alzheimers disease and its impact on insurance purchasing behavior. Health Affairs, 24, 483-490. 


\section{Appendix A. Additional summary details and correlation coefficients}

Table A.3: Summary Statistics II

\begin{tabular}{l|l|ll}
\hline & $\begin{array}{l}\text { Full Sample } \\
\text { No. of obs. }\end{array}$ & $\begin{array}{l}\text { No intention } \\
\text { No. of obs. }\end{array}$ & $\begin{array}{l}\text { Intention } \\
\text { No. of obs. }\end{array}$ \\
\hline Australia & 671 & 421 & 250 \\
Brazil & 744 & 330 & 414 \\
Germany & 580 & 277 & 303 \\
Hong Kong & 311 & 171 & 140 \\
Italy & 679 & 239 & 440 \\
Malaysia & 317 & 85 & 232 \\
Mexico & 515 & 149 & 366 \\
Spain & 648 & 349 & 299 \\
Switzerland & 569 & 270 & 299 \\
UK & 904 & 521 & 383 \\
USA & 543 & 254 & 289 \\
\hline Advertising/PR & 54 & 21 & 33 \\
Automotive Industry & 94 & 43 & 51 \\
Construction and Building & 267 & 109 & 158 \\
Education, Training and Science & 627 & 309 & 318 \\
Engineering and Manufacturing & 323 & 129 & 194 \\
Facility Services & 218 & 77 & 141 \\
Financial Services Company & 201 & 96 & 105 \\
General Management/Policy & 289 & 121 & 168 \\
Hospitality & 193 & 97 & 96 \\
Information and Communications (ICT) Services & 282 & 128 & 154 \\
Journalism & 28 & 15 & 13 \\
Leisure and Hospitality & 131 & 71 & 60 \\
Logistics & 224 & 93 & 131 \\
Market Research & 28 & 16 & 12 \\
Medical Services, Health and Socio-cultural Wellbeing & 470 & 227 & 243 \\
Police, Security or Defence & 107 & 55 & 52 \\
Retail & 715 & 352 & 363 \\
Other & 1.748 & 848 & 900 \\
I am not currently employed & 482 & 259 & 223 \\
\hline
\end{tabular}


Table A.4: Correlation matrix: Full Sample of 6481 individuals

\begin{tabular}{|c|c|c|c|c|c|c|c|c|c|c|c|c|c|c|c|}
\hline & $\begin{array}{l}\text { Personal } \\
\text { exp. }\end{array}$ & $\begin{array}{l}\text { Vicarious } \\
\text { exp. }\end{array}$ & $\begin{array}{l}\text { Personal } \\
\text { risk }\end{array}$ & $\begin{array}{c}\text { Better } \\
\text { than avg. } \\
\text { health }\end{array}$ & $\begin{array}{c}\text { Future } \\
\text { health better } \\
\text { than now }\end{array}$ & Male & Age & $\begin{array}{c}\text { Children } \\
<18\end{array}$ & $\begin{array}{c}\text { \# of } \\
\text { people rely } \\
\text { on income }\end{array}$ & Income & Employee & $\begin{array}{c}\text { Fin. } \\
\text { Literacy }\end{array}$ & Educ. & $\begin{array}{l}\text { Risk } \\
\text { ave. }\end{array}$ & $\begin{array}{l}\text { Insur. } \\
\text { demand }\end{array}$ \\
\hline $\begin{array}{l}\text { Personal } \\
\text { exp. }\end{array}$ & 1 & & & & & & & & & & & & & & \\
\hline $\begin{array}{l}\text { Vicarious } \\
\text { exp. }\end{array}$ & $0.200^{* * *}$ & 1 & & & & & & & & & & & & & \\
\hline $\begin{array}{l}\text { Personal } \\
\text { risk }\end{array}$ & $0.148^{* * *}$ & $0.132^{* * *}$ & 1 & & & & & & & & & & & & \\
\hline $\begin{array}{l}\text { Better } \\
\text { than avg. } \\
\text { health }\end{array}$ & $-0.0303 *$ & -0.005 & $-0.107^{* * *}$ & 1 & & & & & & & & & & & \\
\hline $\begin{array}{c}\text { Future } \\
\text { health better } \\
\text { than now }\end{array}$ & $0.072^{* * *}$ & 0.007 & 0.0133 & $-0.0870^{* * *}$ & 1 & & & & & & & & & & \\
\hline Male & 0.008 & $-0.049^{* * *}$ & -0.001 & $0.029^{*}$ & -0.0186 & 1 & & & & & & & & & \\
\hline Age & -0.016 & 0.012 & $0.038^{* *}$ & -0.0220 & $-0.180^{* * *}$ & $0.0364^{* *}$ & 1 & & & & & & & & \\
\hline $\begin{array}{c}\text { Children } \\
\quad<18\end{array}$ & 0.022 & $0.035^{* * *}$ & $0.044^{* * *}$ & -0.003 & 0.021 & $-0.056^{* * *}$ & $-0.115^{* * *}$ & 1 & & & & & & & \\
\hline $\begin{array}{c}\text { \# of } \\
\text { people rely } \\
\text { on income }\end{array}$ & 0.010 & $0.062^{* * *}$ & $0.072 * * *$ & -0.007 & 0.019 & $0.058^{* * *}$ & $-0.039^{* *}$ & $0.494^{* * *}$ & 1 & & & & & & \\
\hline Income & $-0.067^{* * *}$ & $-0.097^{* * *}$ & $-0.063^{* * *}$ & $0.027^{*}$ & -0.0005 & 0.010 & -0.008 & $0.078^{* * *}$ & $0.080^{* * *}$ & 1 & & & & & \\
\hline Employee & $-0.045^{* * *}$ & $-0.066^{* * *}$ & $-0.043^{* * *}$ & $-0.0523^{* * *}$ & $-0.0249^{*}$ & -0.0115 & $-0.0704^{* * *}$ & $0.0359^{* *}$ & $0.0292^{*}$ & $0.183^{* * *}$ & 1 & & & & \\
\hline $\begin{array}{c}\text { Fin. } \\
\text { Literacy }\end{array}$ & $-0.043^{* * *}$ & 0.014 & $-0.079^{* * *}$ & 0.007 & $-0.154^{* * *}$ & $0.075^{* * *}$ & $0.200^{* * *}$ & $-0.063^{* * *}$ & $-0.083^{* * *}$ & $0.123^{* * *}$ & 0.003 & 1 & & & \\
\hline Educ. & -0.022 & -0.002 & $-0.042^{* * *}$ & $0.025^{*}$ & -0.011 & $-0.034^{* *}$ & $-0.045^{* * *}$ & 0.004 & -0.024 & $0.110^{* * *}$ & 0.010 & $0.147^{* * *}$ & 1 & & \\
\hline $\begin{array}{l}\text { Risk } \\
\text { ave. }\end{array}$ & $-0.075^{* * *}$ & $-0.076^{* * *}$ & -0.00534 & $-0.120^{* * *}$ & $-0.0690^{* * *}$ & $-0.118^{* * *}$ & $0.157^{* * *}$ & $-0.061^{* * *}$ & $-0.052^{* * *}$ & $-0.150^{* * *}$ & -0.00233 & -0.014 & $-0.044^{* * *}$ & 1 & \\
\hline $\begin{array}{l}\text { Insur. } \\
\text { demand }\end{array}$ & $0.110^{* * *}$ & $0.114^{* * *}$ & $0.090^{* * *}$ & $0.055^{* * *}$ & $0.058^{* * *}$ & $0.038^{* * *}$ & $-0.142^{* * *}$ & $0.127^{* * *}$ & $0.127^{* * *}$ & $0.280^{* * *}$ & $0.098^{* * *}$ & $-0.084^{* * *}$ & $0.0491^{* * *}$ & $-0.262^{* * *}$ & 1 \\
\hline
\end{tabular}




\section{Appendix B. Robustness checks}

Table B.5: The effect of physical, emotional and vicarious experience on intention to purchase insurance

\begin{tabular}{|c|c|c|c|c|c|}
\hline & \multicolumn{5}{|c|}{ Intention to purchase insurance } \\
\hline & \multicolumn{4}{|c|}{ Full sample } & \multirow{2}{*}{$\begin{array}{c}\text { Above median } \\
\text { income } \\
(5)\end{array}$} \\
\hline & $(1)$ & $(2)$ & (3) & (4) & \\
\hline Physical experience & $\begin{array}{c}0.524^{* * *} \\
(0.055)\end{array}$ & & & $\begin{array}{c}0.317^{* * *} \\
(0.061)\end{array}$ & $\begin{array}{c}0.452^{* * *} \\
(0.096)\end{array}$ \\
\hline Emotional experience & & $\begin{array}{c}0.554^{* * *} \\
(0.050)\end{array}$ & & $\begin{array}{c}0.309^{* * *} \\
(0.049)\end{array}$ & $\begin{array}{l}0.393^{*} \\
(0.184)\end{array}$ \\
\hline Vicarious experience & & & $\begin{array}{c}0.798^{* * *} \\
(0.086)\end{array}$ & $\begin{array}{c}0.723^{* * *} \\
(0.088)\end{array}$ & $\begin{array}{c}0.729^{* * *} \\
(0.068)\end{array}$ \\
\hline Personal risk & $\begin{array}{c}0.065^{* * *} \\
(0.018)\end{array}$ & $\begin{array}{c}0.070^{* * *} \\
(0.017)\end{array}$ & $\begin{array}{c}0.057^{* * *} \\
(0.017)\end{array}$ & $\begin{array}{l}0.041^{*} \\
(0.018)\end{array}$ & $\begin{array}{c}0.040 \\
(0.023)\end{array}$ \\
\hline $\begin{array}{l}\text { Better than } \\
\text { avg. health }\end{array}$ & $-0.125^{*}$ & $-0.124^{*}$ & -0.128 & -0.120 & $-0.319^{* *}$ \\
\hline & $(0.062)$ & $(0.059)$ & $(0.066)$ & $(0.067)$ & $(0.113)$ \\
\hline Higher future health & $\begin{array}{c}0.093 \\
(0.097)\end{array}$ & $\begin{array}{c}0.084 \\
(0.096)\end{array}$ & $\begin{array}{c}0.108 \\
(0.101)\end{array}$ & $\begin{array}{c}0.074 \\
(0.103)\end{array}$ & $\begin{array}{c}0.098 \\
(0.163)\end{array}$ \\
\hline Male & $\begin{array}{l}0.015 \\
(0.041)\end{array}$ & $\begin{array}{c}0.029 \\
(0.037)\end{array}$ & $\begin{array}{c}0.062 \\
(0.038)\end{array}$ & $\begin{array}{c}0.062 \\
(0.036)\end{array}$ & $\begin{array}{l}0.133 \\
(0.073)\end{array}$ \\
\hline Age & $\begin{array}{c}-0.026^{* * *} \\
(0.004)\end{array}$ & $\begin{array}{c}-0.024^{* * *} \\
(0.004)\end{array}$ & $\begin{array}{c}-0.026^{* * *} \\
(0.004)\end{array}$ & $\begin{array}{c}-0.026^{* * *} \\
(0.004)\end{array}$ & $\begin{array}{c}-0.028^{* * *} \\
(0.005)\end{array}$ \\
\hline children $<18$ & $\begin{array}{c}0.332^{* * *} \\
(0.079)\end{array}$ & $\begin{array}{c}0.344^{* * *} \\
(0.079)\end{array}$ & $\begin{array}{c}0.360^{* * *} \\
(0.077)\end{array}$ & $\begin{array}{c}0.356^{* * *} \\
(0.075)\end{array}$ & $\begin{array}{l}0.344^{* *} \\
(0.111)\end{array}$ \\
\hline $\begin{array}{l}\text { \# people } \\
\text { rely on income }\end{array}$ & $0.081^{*}$ & $0.083^{*}$ & 0.064 & $0.066^{*}$ & 0.043 \\
\hline & $(0.032)$ & $(0.033)$ & $(0.034)$ & $(0.032)$ & $(0.044)$ \\
\hline $\begin{array}{r}\text { Education } \\
\text { (years of) }\end{array}$ & -0.004 & -0.005 & -0.004 & -0.003 & 0.009 \\
\hline & $(0.006)$ & $(0.006)$ & $(0.006)$ & $(0.006)$ & $(0.010)$ \\
\hline $\begin{array}{l}\text { Bottom } 25 \% \text { of } \\
\text { current income }\end{array}$ & $\begin{array}{c}-0.302^{* * *} \\
(0.068)\end{array}$ & $\begin{array}{c}-0.309^{* * *} \\
(0.064)\end{array}$ & $\begin{array}{c}-0.311^{* * *} \\
(0.067)\end{array}$ & $\begin{array}{c}-0.319 * * * \\
(0.069)\end{array}$ & \\
\hline $\begin{array}{l}\text { Top } 25 \% \text { of } \\
\text { current income }\end{array}$ & $0.346^{* * *}$ & $0.339^{* * *}$ & $0.350^{* * *}$ & $0.362^{* * *}$ & 0.012 \\
\hline & $(0.064)$ & $(0.063)$ & $(0.073)$ & $(0.070)$ & $(0.088)$ \\
\hline Employee & $\begin{array}{l}-0.026 \\
(0.102)\end{array}$ & $\begin{array}{l}-0.007 \\
(0.101)\end{array}$ & $\begin{array}{c}0.009 \\
(0.110)\end{array}$ & $\begin{array}{c}0.027 \\
(0.106)\end{array}$ & $\begin{array}{l}-0.121 \\
(0.202)\end{array}$ \\
\hline Constant & $\begin{array}{c}0.057 \\
(0.256)\end{array}$ & $\begin{array}{l}-0.032 \\
(0.251)\end{array}$ & $\begin{array}{l}-0.119 \\
(0.285)\end{array}$ & $\begin{array}{l}-0.238 \\
(0.288)\end{array}$ & $\begin{array}{c}0.019 \\
(0.411)\end{array}$ \\
\hline $\begin{array}{r}\text { Country } \\
\text { dummies }\end{array}$ & Yes & Yes & Yes & Yes & Yes \\
\hline $\begin{array}{r}\text { Occupation } \\
\text { dummies }\end{array}$ & Yes & Yes & Yes & Yes & Yes \\
\hline $\mathrm{N}$ & 6001 & 6001 & 6001 & 6001 & 1919 \\
\hline $\mathrm{BIC}$ & 7707 & 7721 & 7587 & 7527 & 2367 \\
\hline Pseudo $R^{2}$ & 0.08 & 0.08 & 0.10 & 0.10 & 0.11 \\
\hline
\end{tabular}

Notes: Unstandardised coefficients of logistic regressions. Robust standard errors in parenthesis. standard errors clustered at the country level ${ }^{*} \mathrm{p}<0.05,{ }^{* *} \mathrm{p}<0.01,{ }^{* * *} \mathrm{p}<0.001$. 


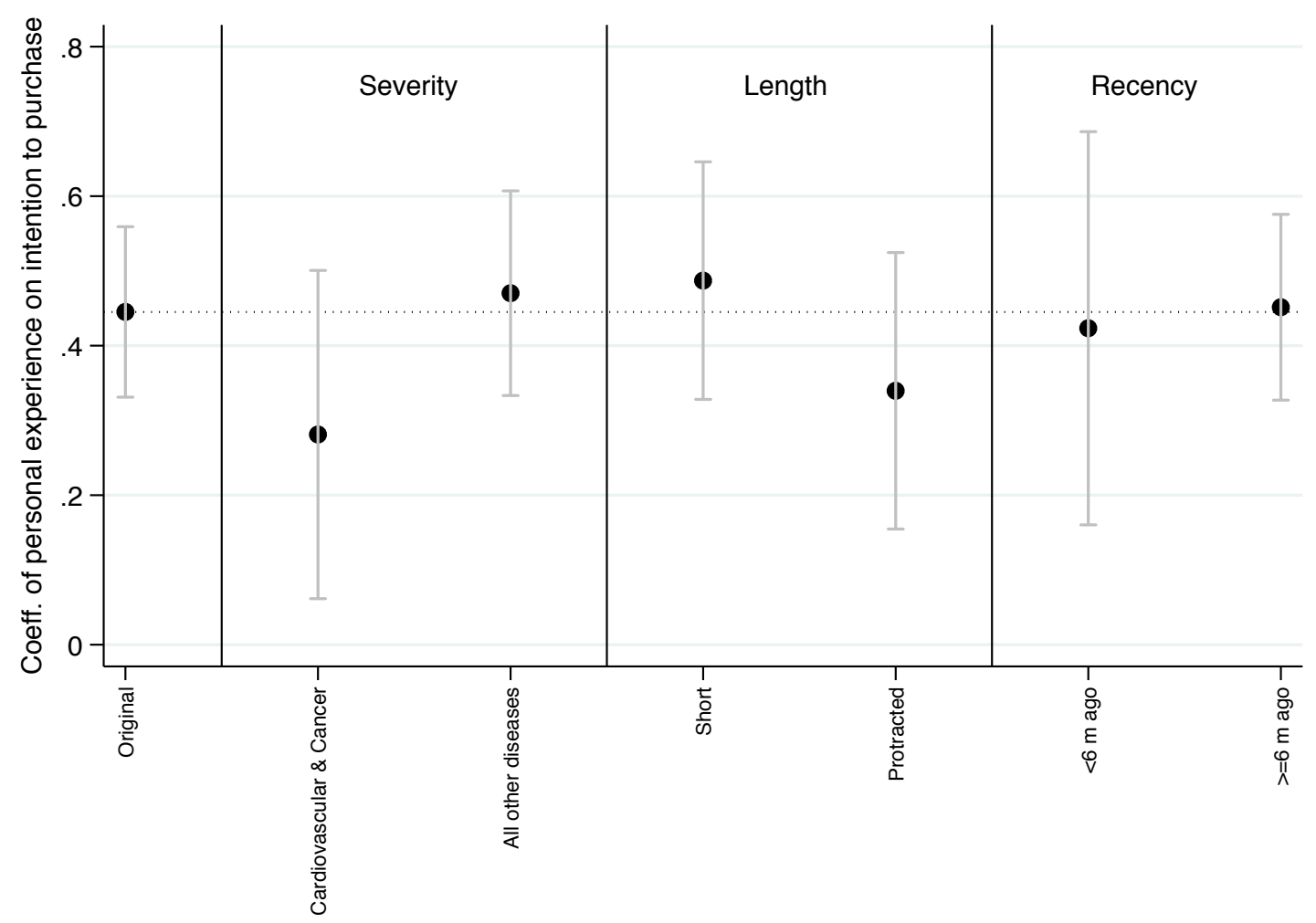

Notes: "Original" identifies the coefficient of personal experience presented in column 4 in table 2. Subsequently, we distinguish experience depending on its seriousness and timing and evaluate its effect on intentions. In each model, we consider vicarious experience as well as the full set of controls discussed above including occupation and country dummies. Unstandardised coefficients of logistic regression as well as their $95 \%$ confidence intervals are reported here.

Figure B.2: Effect of different types of personal experience on intentions to purchase insurance 
Table B.6: Risk aversion, knowledge financial literacy and the intention to purchase insurance

\begin{tabular}{|c|c|c|c|c|c|c|}
\hline & \multicolumn{6}{|c|}{ Intention to purchase insurance } \\
\hline & \multicolumn{2}{|c|}{ Risk aversion } & \multicolumn{2}{|c|}{ Knowledge of insurance } & \multicolumn{2}{|c|}{ Financial literacy } \\
\hline & (1) & $(2)$ & (3) & (4) & (5) & (6) \\
\hline Personal Exp. & $\begin{array}{c}0.418^{* * *} \\
(0.059)\end{array}$ & $\begin{array}{c}0.605^{* *} \\
(0.214)\end{array}$ & $\begin{array}{c}0.400^{* * *} \\
(0.062)\end{array}$ & $\begin{array}{l}0.368^{*} \\
(0.180)\end{array}$ & $\begin{array}{c}0.447^{* * *} \\
(0.059)\end{array}$ & $\begin{array}{c}0.556^{* * *} \\
(0.113)\end{array}$ \\
\hline Vicarious Exp. & $\begin{array}{c}0.694^{* * *} \\
(0.084)\end{array}$ & $\begin{array}{c}0.625^{* * *} \\
(0.146)\end{array}$ & $\begin{array}{c}0.686^{* * *} \\
(0.091)\end{array}$ & $\begin{array}{c}0.869^{* * *} \\
(0.192)\end{array}$ & $\begin{array}{c}0.718^{* * *} \\
(0.086)\end{array}$ & $\begin{array}{c}0.879^{* * *} * \\
(0.147)\end{array}$ \\
\hline Risk Aversion & $\begin{array}{c}-0.208^{* * *} \\
(0.022)\end{array}$ & $\begin{array}{c}-0.197^{* * *} \\
(0.035)\end{array}$ & & & & \\
\hline Per. Exp. $\times$ Risk Aversion & & $\begin{array}{l}-0.051 \\
(0.056)\end{array}$ & & & & \\
\hline Vic. Exp. $\times$ Risk Aversion & & $\begin{array}{c}0.019 \\
(0.032)\end{array}$ & & & & \\
\hline Knowledge of insurance & & & $\begin{array}{c}0.254^{* * *} \\
(0.036)\end{array}$ & $\begin{array}{c}0.283^{* * *} \\
(0.061)\end{array}$ & & \\
\hline Per. Exp. $\times$ Know. Ins & & & & $\begin{array}{c}0.012 \\
(0.059)\end{array}$ & & \\
\hline Vic. Exp. $\times$ Know. Ins & & & & $\begin{array}{l}-0.070 \\
(0.079)\end{array}$ & & \\
\hline Fin. lit. & & & & & $\begin{array}{l}0.062 \\
(0.037)\end{array}$ & $\begin{array}{l}0.119^{*} \\
(0.050)\end{array}$ \\
\hline Per. Exp. $\times$ Fin. lit. & & & & & & $\begin{array}{l}-0.055 \\
(0.033)\end{array}$ \\
\hline Vic. Exp. $\times$ Fin. lit. & & & & & & $\begin{array}{l}-0.080^{*} \\
(0.040)\end{array}$ \\
\hline Personal risk & $\begin{array}{l}0.042^{*} \\
(0.018)\end{array}$ & $\begin{array}{l}0.042^{*} \\
(0.018)\end{array}$ & $\begin{array}{c}0.037 \\
(0.019)\end{array}$ & $\begin{array}{c}0.037 \\
(0.019)\end{array}$ & $\begin{array}{l}0.044^{*} \\
(0.018)\end{array}$ & $\begin{array}{l}0.044^{*} \\
(0.018)\end{array}$ \\
\hline Constant & $\begin{array}{l}0.446 \\
(0.311)\end{array}$ & $\begin{array}{l}0.404 \\
(0.300)\end{array}$ & $\begin{array}{c}-0.827^{* *} \\
(0.291)\end{array}$ & $\begin{array}{c}-0.903^{* *} \\
(0.309)\end{array}$ & $\begin{array}{l}-0.327 \\
(0.307)\end{array}$ & $\begin{array}{l}-0.453 \\
(0.311)\end{array}$ \\
\hline $\begin{array}{l}\text { Country } \\
\text { dummies }\end{array}$ & Yes & Yes & Yes & Yes & Yes & Yes \\
\hline $\begin{array}{r}\text { Occupation } \\
\text { dummies }\end{array}$ & Yes & Yes & Yes & Yes & Yes & Yes \\
\hline $\begin{array}{r}\text { Personal } \\
\text { characteristics }\end{array}$ & Yes & Yes & Yes & Yes & Yes & Yes \\
\hline $\mathrm{N}$ & 6001 & 6001 & 6001 & 6001 & 6001 & 6001 \\
\hline $\mathrm{BIC}$ & 7455 & 7454 & 7470 & 7469 & 7527 & 7524 \\
\hline Pseudo $R^{2}$ & 0.11 & 0.11 & 0.11 & 0.11 & 0.10 & 0.10 \\
\hline
\end{tabular}

Notes: Unstandardised coefficients of logistic regressions. Robust standard errors in parenthesis. Standard errors clustered at the country level, ${ }^{*} \mathrm{p}<0.05,{ }^{* *} \mathrm{p}<0.01,{ }^{* * *} \mathrm{p}<0.001$.

Personal characteristics include age, gender, family structure, education, current income, a dummy for dependent employment, a dummy for current health and one for future health status. These are included in all models presented in this table. 


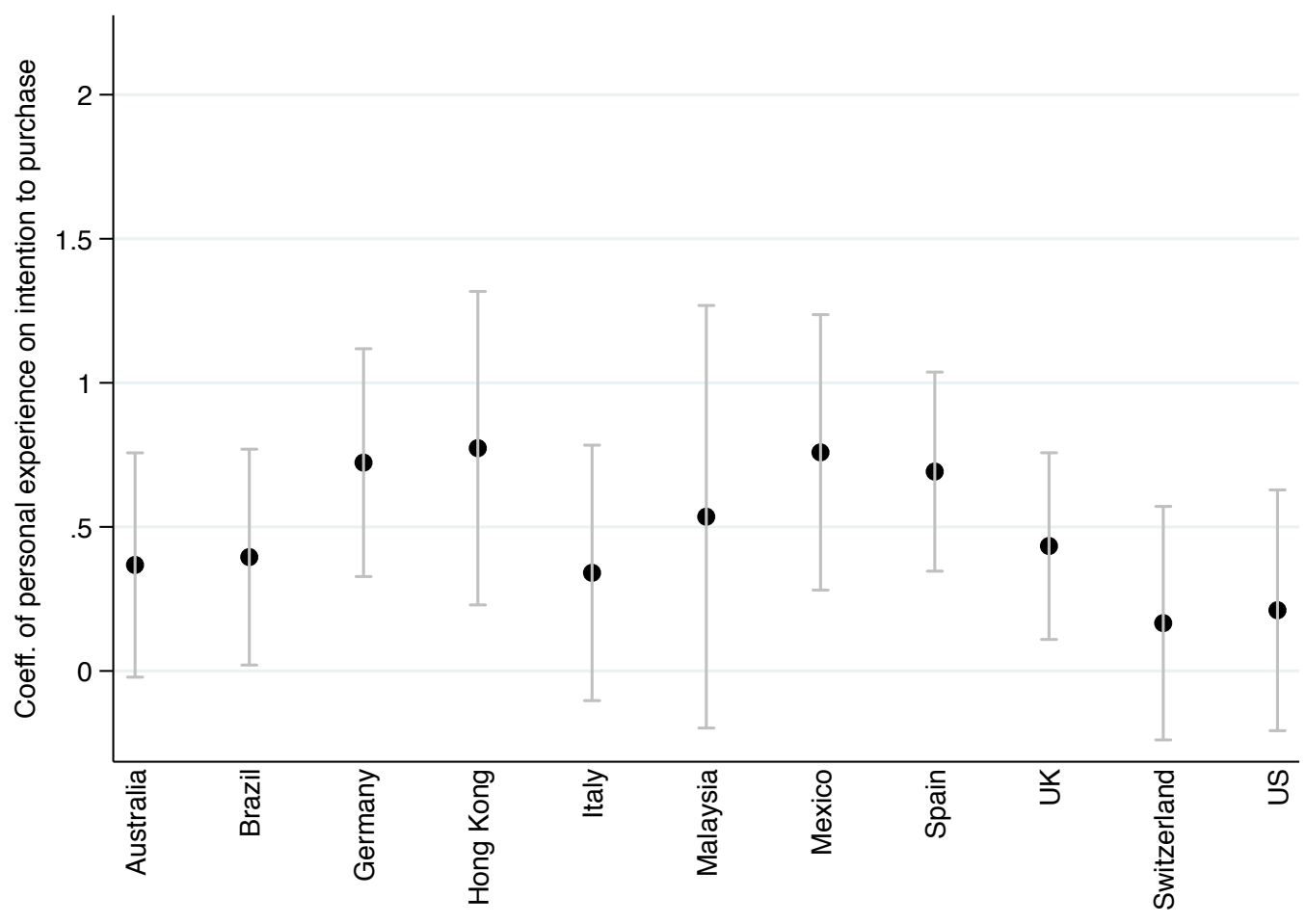

(a) Personal experience

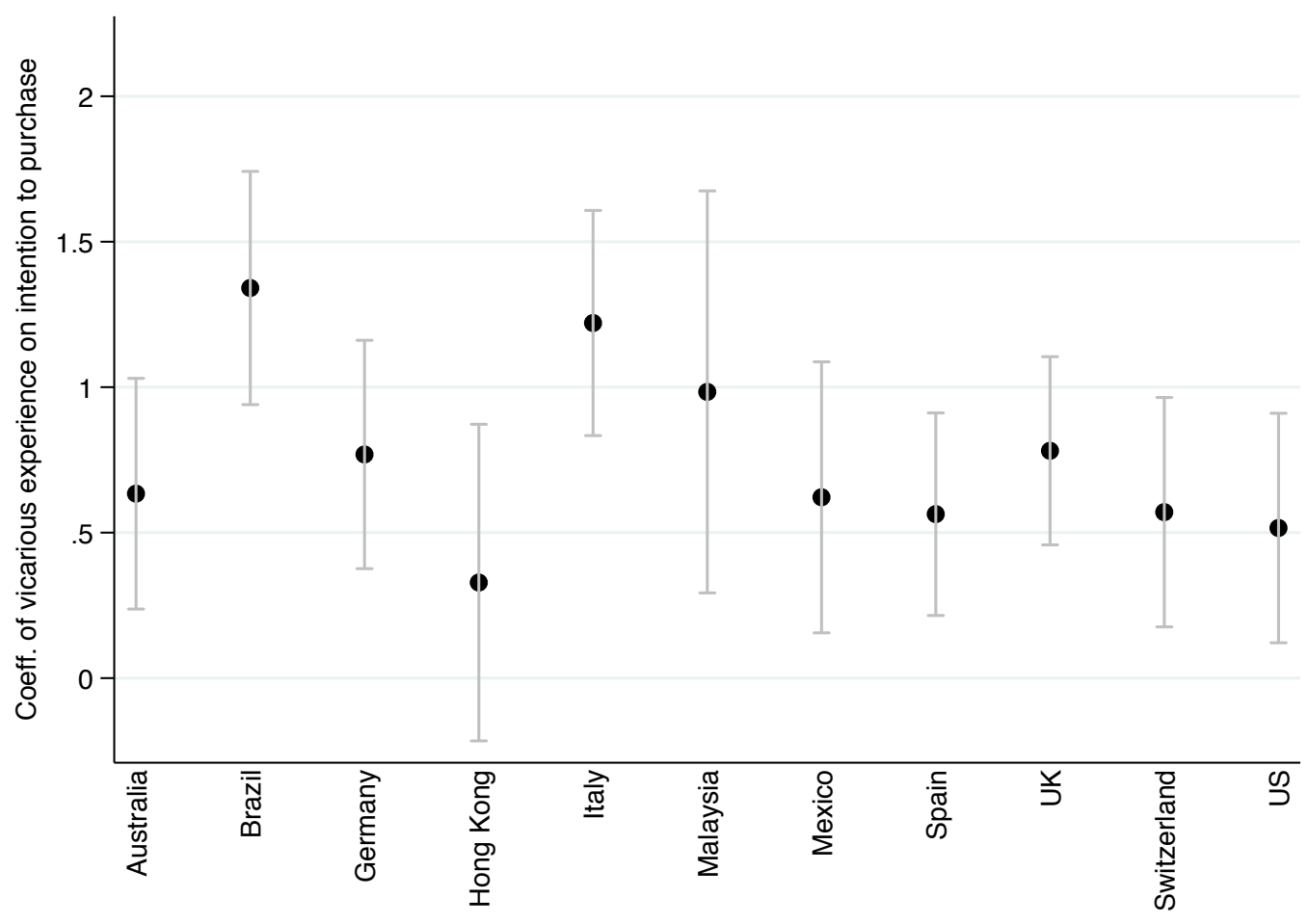

(b) Vicarious experience

Notes: For each country, we regress intention to purchase on both types of experience and the full set of controls described above, including occupation dummies, and plot the resulting unstandardised experience coefficients as well as their $95 \%$ confidence intervals. Positive coefficients imply that past negative health experiences, be they first- or second-hand, increase purchase intentions.

Figure B.3: Effect of experience on intention to purchase insurance in 11 countries 
Table B.7: The effect of personal and vicarious experience on actual insurance ownership

\begin{tabular}{|c|c|c|c|c|c|c|}
\hline & \multicolumn{6}{|c|}{ Insurance ownership } \\
\hline & \multicolumn{4}{|c|}{ Full sample } & \multirow{2}{*}{$\begin{array}{l}\text { Above median } \\
\text { income } \\
(5)\end{array}$} & \multirow{2}{*}{$\begin{array}{c}\text { Full sample } \\
\qquad(6)\end{array}$} \\
\hline & (1) & (2) & (3) & (4) & & \\
\hline Personal Experience & $\begin{array}{c}0.372^{* * *} \\
(0.071)\end{array}$ & $\begin{array}{c}0.343^{* * *} \\
(0.069)\end{array}$ & $\begin{array}{c}0.348^{* * *} \\
(0.068)\end{array}$ & $\begin{array}{c}0.335^{* * *} \\
(0.070)\end{array}$ & $\begin{array}{c}0.322^{* * *} \\
(0.097)\end{array}$ & $\begin{array}{c}0.336^{* * *} \\
(0.069)\end{array}$ \\
\hline Vicarious Experience & $\begin{array}{c}0.481^{* * *} * \\
(0.055)\end{array}$ & $\begin{array}{c}0.457^{* * *} \\
(0.055)\end{array}$ & $\begin{array}{c}0.449^{* * *} \\
(0.054)\end{array}$ & $\begin{array}{c}0.449^{* * *} \\
(0.053)\end{array}$ & $\begin{array}{c}0.443^{* * *} \\
(0.078)\end{array}$ & $\begin{array}{c}0.439^{* * *} \\
(0.052)\end{array}$ \\
\hline Personal risk & & $\begin{array}{c}0.062^{* * *} \\
(0.011)\end{array}$ & $\begin{array}{c}0.069^{* * *} \\
(0.012)\end{array}$ & $\begin{array}{c}0.069^{* * *} \\
(0.012)\end{array}$ & $\begin{array}{c}0.081^{* * *} \\
(0.017)\end{array}$ & $\begin{array}{c}0.071^{* * *} \\
(0.012)\end{array}$ \\
\hline $\begin{array}{l}\text { Better than } \\
\text { avg health }\end{array}$ & & & $0.285^{* * *}$ & $0.302^{* * *}$ & 0.139 & $0.285^{* * *}$ \\
\hline Higher future health & & & $(0.067)$ & $\begin{array}{l}(0.070) \\
0.175^{*} \\
(0.085)\end{array}$ & $\begin{array}{c}(0.081) \\
0.079 \\
(0.085)\end{array}$ & $\begin{array}{l}(0.066) \\
0.172^{*} \\
(0.086)\end{array}$ \\
\hline Male & $\begin{array}{l}0.146^{*} \\
(0.066)\end{array}$ & $\begin{array}{l}0.148^{*} \\
(0.066)\end{array}$ & $\begin{array}{l}0.142^{*} \\
(0.066)\end{array}$ & $\begin{array}{l}0.145^{*} \\
(0.064)\end{array}$ & $\begin{array}{c}0.116 \\
(0.104)\end{array}$ & $\begin{array}{l}0.143^{*} \\
(0.064)\end{array}$ \\
\hline Age & $\begin{array}{c}-0.016^{* * *} \\
(0.004)\end{array}$ & $\begin{array}{c}-0.016^{* * *} \\
(0.004)\end{array}$ & $\begin{array}{c}-0.016^{* * *} \\
(0.004)\end{array}$ & $\begin{array}{c}-0.014^{* * *} \\
(0.004)\end{array}$ & $\begin{array}{c}-0.020^{* * *} \\
(0.004)\end{array}$ & $\begin{array}{c}-0.013^{* * *} \\
(0.004)\end{array}$ \\
\hline $\begin{array}{l}\text { \# people } \\
\text { rely on income }\end{array}$ & 0.040 & 0.036 & 0.037 & 0.037 & 0.094 & 0.037 \\
\hline & $(0.032)$ & $(0.032)$ & $(0.032)$ & $(0.032)$ & $(0.048)$ & $(0.032)$ \\
\hline children $<18$ & $\begin{array}{c}0.282^{* * *} \\
(0.077)\end{array}$ & $\begin{array}{c}0.279^{* * *} \\
(0.077)\end{array}$ & $\begin{array}{c}0.280^{* * *} \\
(0.077)\end{array}$ & $\begin{array}{c}0.281^{* * *} \\
(0.078)\end{array}$ & $\begin{array}{c}0.277^{* * *} \\
(0.081)\end{array}$ & $\begin{array}{c}0.280^{* * *} \\
(0.078)\end{array}$ \\
\hline $\begin{array}{l}\text { Education } \\
\text { (vears of) }\end{array}$ & 0.006 & 0.006 & 0.007 & 0.006 & 0.012 & 0.006 \\
\hline & $(0.009)$ & $(0.008)$ & $(0.008)$ & $(0.008)$ & $(0.009)$ & $(0.008)$ \\
\hline $\begin{array}{l}\text { Bottom } 25 \% \text { of } \\
\text { current income }\end{array}$ & $-0.453^{* * *}$ & $-0.463^{* * *}$ & $-0.460^{* * *}$ & $-0.459^{* * *}$ & & $-0.455^{* * *}$ \\
\hline & $(0.065)$ & $(0.066)$ & $(0.064)$ & $(0.065)$ & & $(0.065)$ \\
\hline $\begin{array}{l}\text { Top } 25 \% \text { of } \\
\text { current income }\end{array}$ & $0.438^{* * *}$ & $0.439^{* * *}$ & $0.424^{* * *}$ & $0.428^{* * *}$ & 0.183 & $0.419^{* * *}$ \\
\hline & $(0.081)$ & $(0.079)$ & $(0.075)$ & $(0.074)$ & $(0.105)$ & $(0.075)$ \\
\hline Employee & $\begin{array}{c}0.280^{* *} \\
(0.103)\end{array}$ & $\begin{array}{c}0.282^{* *} \\
(0.102)\end{array}$ & $\begin{array}{c}0.290^{* *} \\
(0.102)\end{array}$ & $\begin{array}{c}0.292^{* *} \\
(0.102)\end{array}$ & $\begin{array}{c}0.137 \\
(0.141)\end{array}$ & $\begin{array}{c}0.297^{\text {** }} \\
(0.102)\end{array}$ \\
\hline Higher future income & & & & & & $\begin{array}{c}0.160^{* * *} \\
(0.044)\end{array}$ \\
\hline Constant & $\begin{array}{c}-1.175^{* * *} \\
(0.195)\end{array}$ & $\begin{array}{c}-1.282^{* * *} \\
(0.187)\end{array}$ & $\begin{array}{c}-1.397^{* * *} \\
(0.176)\end{array}$ & $\begin{array}{c}-1.513^{* * *} \\
(0.185)\end{array}$ & $\begin{array}{c}-1.109^{* * *} \\
(0.271)\end{array}$ & $\begin{array}{c}-1.601^{* * *} \\
(0.189)\end{array}$ \\
\hline $\begin{array}{r}\text { Country } \\
\text { dummies }\end{array}$ & Yes & Yes & Yes & Yes & Yes & Yes \\
\hline $\begin{array}{r}\text { Occupation } \\
\text { dummies }\end{array}$ & Yes & Yes & Yes & Yes & Yes & Yes \\
\hline $\mathrm{N}$ & 10060 & 10060 & 10060 & 10060 & 4099 & 10060 \\
\hline BIC & 11372 & 11350 & 11321 & 11310 & 4986 & 11300 \\
\hline Pseudo $R^{2}$ & 0.15 & 0.15 & 0.15 & 0.15 & 0.13 & 0.15 \\
\hline
\end{tabular}

Notes: Unstandardised coefficients of logistic regressions. Robust standard errors in parenthesis. Standard errors clustered at the country level, ${ }^{*} \mathrm{p}<0.05,{ }^{* *} \mathrm{p}<0.01,{ }^{* * *} \mathrm{p}<0.001$. 